Article

\title{
Puyango, Ecuador Petrified Forest, a Geological Heritage of the Cretaceous Albian-Middle, and Its Relevance for the Sustainable Development of Geotourism
}

\author{
Fernando Morante-Carballo ${ }^{1,2,3, *}$ C , Geanella Herrera-Narváez ${ }^{1,4, *}$, Nelson Jiménez-Orellana ${ }^{4}$ \\ and Paúl Carrión-Mero ${ }^{1,4}$ \\ 1 Centro de Investigación y Proyectos Aplicados a las Ciencias de la Tierra (CIPAT), ESPOL Polytechnic \\ University, Campus Gustavo Galindo Km. 30.5 Vía Perimetral, 9015863 Guayaquil, Ecuador; \\ pcarrion@espol.edu.ec \\ 2 Facultad de Ciencias Naturales y Matemáticas (FCNM), ESPOL Polytechnic University, Campus Gustavo \\ Galindo Km. 30.5 Vía Perimetral, 9015863 Guayaquil, Ecuador \\ 3 Geo-recursos y Aplicaciones GIGA, ESPOL Polytechnic University, Campus Gustavo Galindo Km. 30.5 Vía \\ Perimetral, 9015863 Guayaquil, Ecuador \\ 4 Facultad de Ingeniería en Ciencias de la Tierra (FICT), ESPOL Polytechnic University, Campus Gustavo \\ Galindo Km 30.5 Vía Perimetral, 9015863 Guayaquil, Ecuador; nmjimene@espol.edu.ec \\ * Correspondence: fmorante@espol.edu.ec (F.M.-C.); geamiher@espol.edu.ec (G.H.-N); \\ Tel.: +59-396-976-0276 (F.M.-C.)
}

Received: 7 July 2020; Accepted: 6 August 2020; Published: 14 August 2020

check for updates

\begin{abstract}
Geodiversity treaties have multiplied and given rise to geological heritage as a singular value of protection and preservation for territories. The Puyango Petrified Forest (PPF) is a recognized Ecuadorian reserve, which was declared a National Heritage Treasure. It has an area of 2659 hectares, and it is located in the south of Ecuador, between the provinces of El Oro and Loja. The petrified trunks and trees were buried by volcanic lava, dating from the Cretaceous Period, 96 to 112 million years ago. Thus, silicification and carbonization, two important fossilization events, have produced hundreds of samples of paleontological wealth in Puyango. The objective of this work is to methodologically assess the geodiversity of a fraction of the PPF by registering its geological heritage and value for its preservation and sustainable development. The methodology is based on: (i) Analysis of information on the territory used for tourist visits, as a pilot study area. Presentation of paleontological components and their main sections to enhance their geotouristics value; (ii) Assessment of the geological heritage for its geotourism categorization with a recognized scientific methodology and one proposed by the co-authors propose; and (iii) Analysis of Strengths, Weaknesses, Opportunities, and Threats (SWOT) as a guide for protection and development strategies. Findings reveal the high geotourism potential for a Geopark Project in Puyango, since only 300 hectares are used for tourism and the remaining area is a virgin environment for research and improving knowledge of geodiversity and biodiversity.
\end{abstract}

Keywords: petrified forest; sustainable development; geodiversity; biodiversity; Puyango; geopark

\section{Introduction}

Geodiversity considers all the geological elements of the Earth's crust, from the landscape to its internal structure that constitutes the various materials such as rocks, minerals and fossils. It is an inanimate part of nature, but at the same time significant to sustaining biodiversity, since the soil and subsoil generated by a series of geological processes are what sustain it, and what together are part of the natural beauty of a site; however, geodiversity has been downplayed by historically giving 
greater prominence to biodiversity [1]. Thus, the term geodiversity refers to the quality, spectacularity, and beauty of a site of an abiotic nature, which is why it deserves conservation [2]. The protection and conservation of geodiversity is an issue that until recently was not understood. However, this failure is being overcome thanks to the close link that exists between biodiversity and geodiversity, which can be achieved through proper management to preserve biocenosis and the biotope in an integral way $[3,4]$.

Currently, the geological heritage is promoted and protected adequately towards the sustainable development of geotourism; this term emphasizes a form of tourism to natural areas that focuses explicitly on geology and landscape, promoting geosite tourism and the conservation of geodiversity for a better understanding of the earth sciences through appreciation and learning [5]. In geological terms, a geosite is defined by its scientific value that demonstrates the importance of the geological heritage of a specific area, which must be relevant and of importance to science [6]. This is accomplished through independent visits to geological features, such as geo-trails and viewpoints, guided tours, geo-activities, and the sponsorship of geosite visitor centres $[7,8]$. The term Geoheritage considers particular elements of geodiversity (petrological, geomorphological, structural, mineralogical, paleontological, stratigraphic, hydrogeological, pedological, among others) with a high scientific value [9]. Paleontological heritage of a geosite is the study of its scientific value through fossils, which are testimonies of life in the past, and which also reflect certain events in the geological history of Earth. Around them and the deposits in which they were found, numerous scientific features converge that can be considered objectively, allowing their value to be established; such as fossil types, relative age, state of conservation, among others. Therefore, paleontological heritage is part of the geological and natural heritage [10].

Geodiversity is evident that the fossils and deposits have meaning and provide information on the history of Life and Earth. Morevoer, the scientific component is relevant to place fossils and sites on a theoretical scale of paleontological value [11]. Fossil forests or petrified forests register a remarkable geological-paleontological heritage characterized by the wood of trees that has been buried under sediments and preserved by the absence of oxygen [12]. This type of fossilization is known as permineralization and emphasizes the replacement of the body's molecules by minerals. In this case, petrified wood explains vegetal biodiversity of diverse historical times since it preserves its original structure to a microscopic level.

There are more than 20 specimens of petrified forests worldwide and only 3 belong to Americathe Petrified Forest National Park in Arizona-United States, the Petrified Forest of Santa Cruz Natural Monument in Patagonia, Argentina, and the Puyango Petrified Forest in Ecuador. All these forests are remarkable for their age, surface and paleontological wealth [13]. In Ecuador, forests cover $42 \%$ of the country's total area; half of the area is used for production [14]. Dry forests are of particular importance, since they have less biodiversity than rainforests, but they are the habitat of more than 130 species of birds. These forests are located in two different areas: (a) on the central Pacific coast, which corresponds to the provinces of Esmeraldas, Manabí, Santa Elena and Guayas; and (b) in the southern coast and western foothills of the Andes in El Oro and Loja that comprise the equatorial dry forest with a unique ecosystem in the world [15]. In the past, $35 \%$ of western Ecuador was covered by dry forest. However, $75 \%$ of the area has disappeared due to deforestation pressures and growth of the agricultural and livestock frontier.

Furthermore, PPF is recognized for its heritage as a true paleontological jewel that contains a large number of petrified trees of approximately 100 million years old, where the largest collection of petrified wood in the world is located. One of its largest specimens is the Petrino with dimensions of $2 \mathrm{~m}$ in diameter and $15 \mathrm{~m}$ in length. Its magnificence is given by a large number of petrified trunks that open the door to family, educational, scientific, geological-paleontological and naturist tourism. PPF is a unique beauty in the region with remnants of trees such as trunks and petrified leaves of Mesozoic flora, and fossils of invertebrates such as bivalves, ammonites, echinoderms, among others. Furthermore, its biodiversity coexists protected by the great slopes and breaks of the area $[16,17]$. 
In this regard, this study aims to respond the question: Could we define PPF as a geological heritage and a driving force for geotourism for its spectacularity, good exposure, paleontology, biostratigraphy, and stratigraphic content? Hence, the objective is to methodologically assess the geodiversity of a fraction of PPF as a pilot project, register its outstanding components (geological heritage) and value it for the preservation and sustainable development of the entire forest. For these purposes, an assessment is carried out using the scientific method of the Spanish Inventory of Places of Geological Interest (IELIG, acronym in Spanish) [18]. Moreover, some research-level experiences are recorded to assess sites of geological interest that could be considered as geosites [19,20].

\section{Overview of the Study Area}

Puyango forest is in the southern region of Ecuador, located in the canton Las Lajas, province of El Oro and Puyango-Alamor, canton-parish of the province of Loja. The cantons are divided by the Puyango river, located $7 \mathrm{~km}$ from the border with Peru. The forest occupies an extension of 2658 hectares (Figure 1), and in 1971, it was discovered by the academic staff of the Huaquillas night school that named it "Petrified Forest of Puyango" [20]. In 1973, PPF was declared Cultural Heritage On 9th January 1987 through Ministerial Agreement No. 22, it was declared a protected forest and vegetation due to the efforts of El Oro Cultural Development Center and the Central Bank of Ecuador. Later, in March 1988, it was declared part of the Natural Heritage of Ecuador [21,22].

This region is mountainous, with heights between 360 and 500 m.a.s.l. The current flora and fauna represent a group of transitional forms between the Pacific lowlands and the Andean elevations [23]. The biodiversity of the area corresponds to a tropical dry forest, which is one of the most threatened ecosystems in the world, and its species belong to the Tumbesino Center of endemism owned by Ecuador and Peru [8]. Due to the geomorphological conditions of the area, caused by tectonic events and modeled by the erosion of rivers, PPF presents a great potential for geotourism appeal in this area for the exposure of petrified logs, a product of the fossilization process [24,25].

Puyango Petrified Forest (PPF) is considered one of the few remnants of tropical dry forest in the southwest of the country, where steep slopes and streams such as El Guineo, Las Concreciones, El Chirimoyo, El Limón, Sábalos and Cochurco have preserved the endemic vegetation of its ecosystem and other areas of secondary forest in recovery. In fact, stratigraphic units reveal a fossil richness of invertebrates of the phylum Mollusca and microfossils of foraminifera and calcareous nanofossils [26]. Puyango is an open book of geological succession and paleontological information of high scientific value for society, since it is one of the most representative and relevant forests in South America. PPF has been compared to the Petrified Forest National Park in Arizona, United States-the largest in the world with more than 20,000 hectares. It has petrified tree trunks belonging to the Araucarioxylon arizonicum that are preserved from a conifer corresponding to the Late Triassic Period, already extinct in our times. Moreover, it has fern plant fossils, animals such as the Chinle frogs of the Chinle Geological Formation, and it is the habitat of a great variety of mammals, fauna, birds, reptiles, and amphibians in a desert environment [27]. 


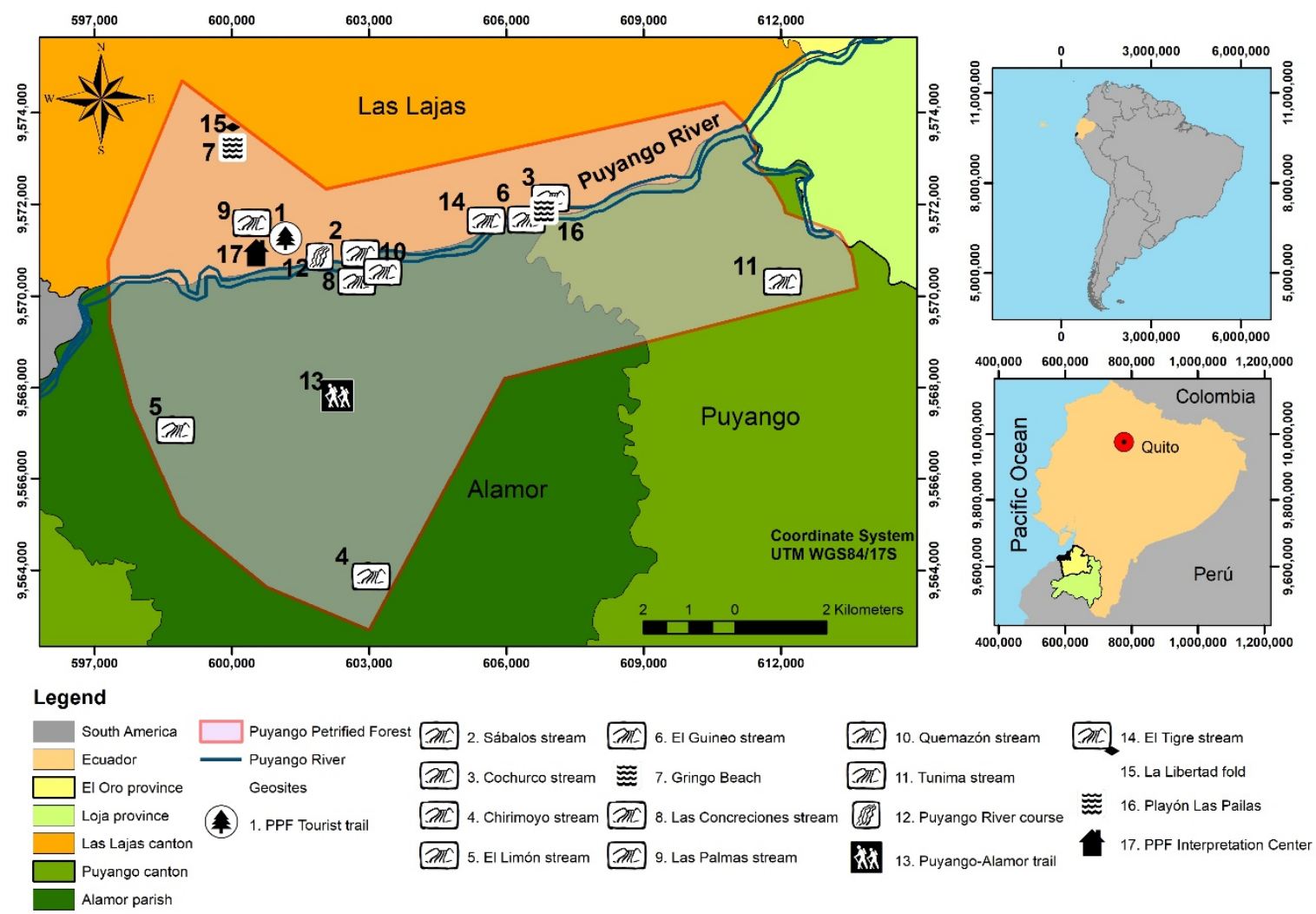

Figure 1. Study area of the Puyango Petrified Forest and its geosites in the provinces of El Oro and Loja. Modified from [28].

Before becoming a tropical dry forest, Puyango was a sea, which dried up and transformed into large hectares of forests and animals. Due to natural cataclysms, geological movements and time, the organisms buried underground arose on the surface forming a trace of the planet's remote past and a transcendent number of ancient and representative fossils that correspond to marine organisms that currently oscillate between 60 and 120 million years [26]. In this regard, Puyango emerged under coastal and terrestrial marine conditions in a relatively narrow basin caused by the continuous erosive tectonism, deformation, displacement, and deposits of pyroclastic materials during the Cretaceous. Before the Andes rose to the end of the Cretaceous 65 million years ago, gymnosperm forests originated on a relatively flat area like the lithified sediments that currently lean in different directions due to folding and tectonism. During this period, the area had a warm temperature. However, with the floods and volcanic activity east of the Andes, the forests were destroyed and deposits of buried trunk layers in alternating sequences of siltstones, sandstones, graywackes and conglomerates were reestablished by erosion [29]. The Andes mountain range slowly submerged the forest, placing it south of its current position in a subtropical climate along with calcium carbonate deposits and the presence of marine fossil invertebrates belonging to shallow water. The geological formation of the site is defined as a sequence of sedimentary rocks of the Late Cretaceous period formed by thin layers of calcareous black shales, crystalline, and massive black limestones, volcanic agglomerates, gray-green siliceous shales, brown shales, and volcano-sedimentary shales (Figure 2). In this type of Cretaceous (Albian-Middle) age materials, the petrified wood is found and in the upper part of the Coquina volcanic material, brown calcareous clays with mollusks and ammonites. In addition, a decreasing sedimentary volcanic grain sequence, clayey sandstones, tobaceous silt with petrified wood and reddish clay can be observed [30]. The trunks were dragged in an aqueous medium of remains of pyroclastic materials and deposited together with the sediments in a marine environment where they were covered by sediments as a result of the erosion of the Andes. Sediments are divided into four geological formations such as the Zapotillo, Cazaderos, Ciano, Ambín and Progreso. Marine 
invertebrate fossils such as gastropods, ostracods, and bivalves, which are associated with microfossils of the order of the foraminifera and calcareous nanophosiles of the Cretaceous (Middle Albian) age, are found in the layers of sedimentary materials [31]. The Puyango river is the limit between the provinces of El Oro and Loja and represents a great geological fault in the East-West direction. It has caused the folding of rocks at the gorges of El Chirimoyo, Cochurco and El Limón streams [32,33].

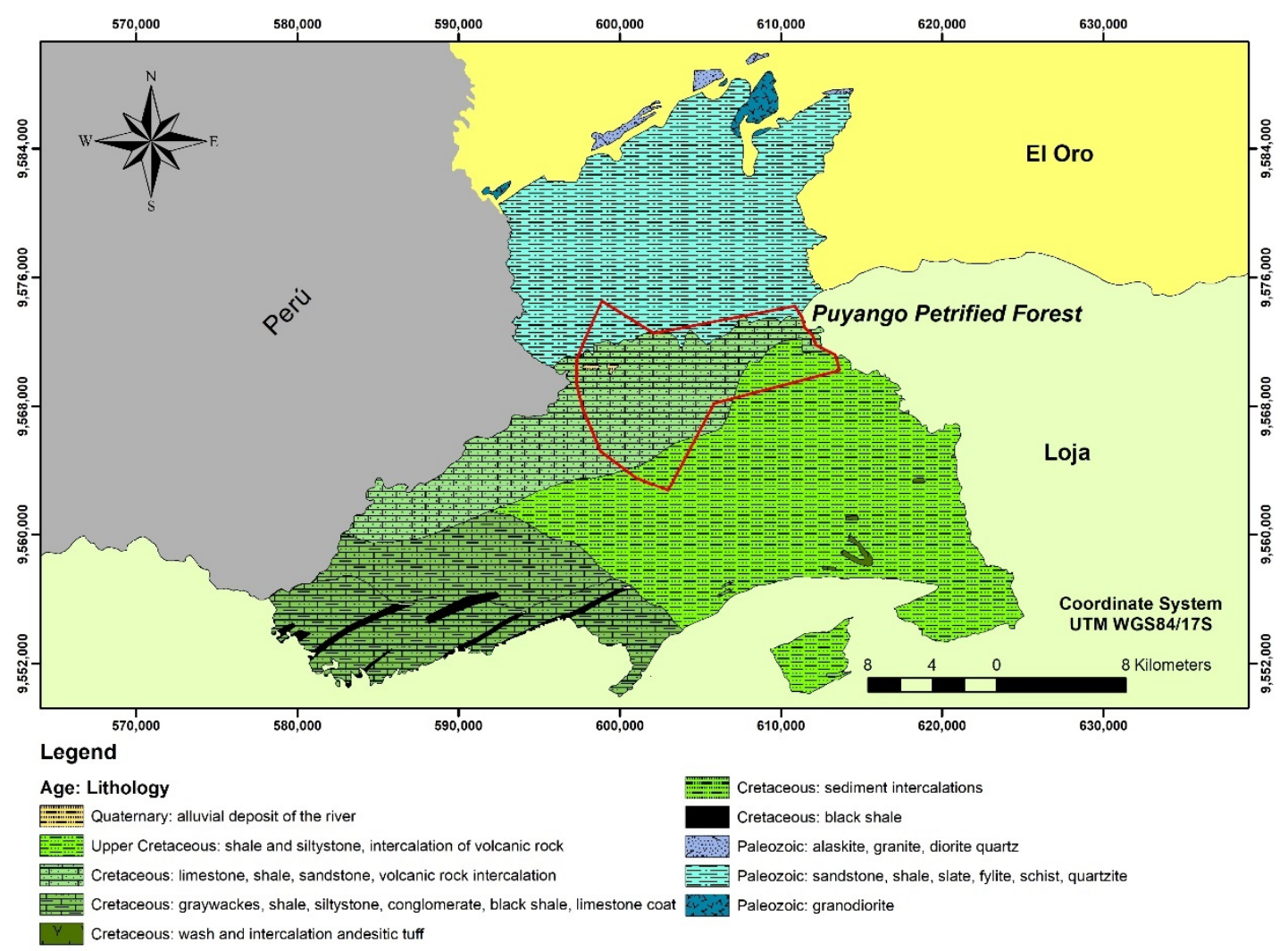

Figure 2. Geological map of the Las Lajas and Puyango cantons of the provinces of El Oro and Loja respectively. Modified from [28].

\section{Materials and Methods}

The proposed methodology for this study comprised three phases (Figure 3): (i) analysis of information from the pilot study area, the case of the Puyango Petrified Forest, scientific information regarding its geological interest, the presentation the paleontological components and their main geotouristic sections; (ii) assessment of the heritage site, using the methodology of the Spanish Inventory of Places of Geological Interest (IELIG, acronym in Spanish) and another proposal by authors to assess its geotouristics potential; and (iii) the results were confirmed with a Strengths, Weaknesses, Opportunities, and Threats (SWOT) analysis, to assess the heritage site status, and propose sustainable development strategies in the SWOT matrix [34]. 


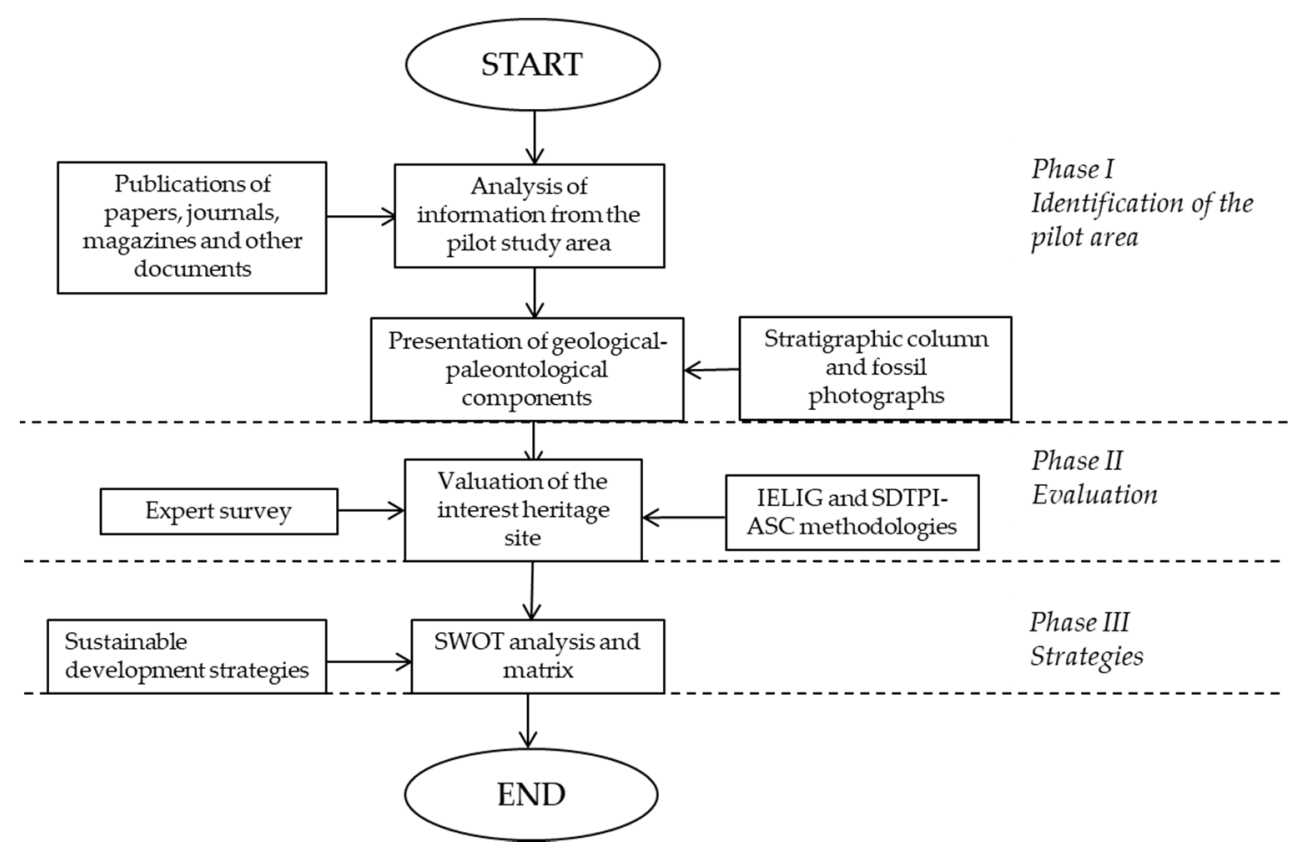

Figure 3. Flowchart of the methodology used for research.

\subsection{First Phase: Identification of the Pilot Area}

In the first phase, the researchers realized a technical visit about the outstanding characteristics of the studied forest, which was carried out with a tourist guide and some national tourists. The route of the place consists of six stations of great geological and paleontological interest, in addition to the collection of historical and scientific information carried out in the sector $[26,29,30]$ through the configuration of a database in scientific publications, works outreach, project reporting and data collection through expert interviews as the basis for further evaluation. This route included the use of database in Geographic Information Systems (GIS) to obtain a map of the tourist route recorded in the Puyango forest.

Finally, this phase included the description geological, paleontological aspects and relevant observations of the geotouristics potential of seventeen possible geosites. We also presented its paleontological components that give the forest an important scientific interest for geologists and paleontologists. Much of its evidence was recorded in fossils such as petrified wood samples and remains of mollusc shell moulds that were found in some streams belonging to the provinces of El Oro and Loja, giving great geotouristics interest to the forest. Besides that, a stratigraphic column belonging to the Las Concreciones stream was described, and finally, it showed pictures of marine fossil invertebrates of the classes of pelecypod and cephalopod molluscs.

\subsection{Second Phase: Quantitative and Qualitative Evaluation}

Moreover, the applied methodology comprises two factors: (1) intrinsic value of the Site of Geological Interest (LIG, acronym in Spanish), highlighting the geological aspects, and (2) use-value of the LIG. Therefore, with the collaboration of paleontologist Nelson Jiménez and archaeologist Jorge Marcos, experts who evaluate the scientific, didactic and touristic premises value, surveys are collected. The experts assign weights to each premise of the methodology developed in [18] (Table 1), where the degrees of Scientific interest (Si), Didactic interest (Di) and Touristic interest (Ti) are obtained. The scores of each parameter vary from $0,1,2$ and 4, where 0 is the lowest score and 4 the highest, scores that are multiplied by the weight of the individual interests given in the methodology (Table 1). 
Table 1. Indicators and weights used for the quantitative assessment of Sites of Geological Interest (LIGs). Modified from [18].

IELIG Methodology

Scientific Weight (Sw), Didactic Weight (Dw), Tourist Weight (Tv), Fragility Weight (Fw) and Vulnerability due to Anthropogenic Threats Weight (Vw)

\begin{tabular}{|c|c|c|c|c|c|c|}
\hline \multirow{2}{*}{ Indicators/Parameters } & \multirow{2}{*}{ Punctuation } & \multicolumn{5}{|c|}{ Weight } \\
\hline & & Sw & Dw & Tw & Fw & Vw \\
\hline Representativeness & & 30 & 5 & & & \\
\hline Prototype location character & & 10 & 5 & & & \\
\hline Degree of scientific knowledge of the place & & 15 & & & & \\
\hline State of conservation & & 10 & 5 & & & \\
\hline Observation conditions & & 10 & 5 & 5 & & \\
\hline Rarity & & 15 & 5 & & & \\
\hline Geological diversity & & 10 & 10 & & & \\
\hline Didactic content & & & 20 & & & \\
\hline Logistics infrastructure & & & 15 & 5 & & \\
\hline Accessibility & & & 15 & 10 & & \\
\hline $\begin{array}{l}\text { Association with other elements of the natural } \\
\text { and/or cultural heritage }\end{array}$ & & & 5 & 5 & & \\
\hline Magnificence or beauty & & & 5 & 20 & & \\
\hline Population density (potential aggression) & $0-4$ & & 5 & 5 & & 5 \\
\hline $\begin{array}{c}\text { Proximity to recreational areas (immediate } \\
\text { potential demand) }\end{array}$ & & & & 5 & & 5 \\
\hline Informative content/Informative use detected & & & & 15 & & \\
\hline $\begin{array}{l}\text { Potential to carry out touristic and recreational } \\
\text { activities }\end{array}$ & & & & 5 & & \\
\hline Socioeconomic environment & & & & 10 & & \\
\hline LIG size & & & & 15 & 40 & \\
\hline Vulnerability to plunder & & & & & 30 & \\
\hline Natural threats & & & & & 30 & \\
\hline $\begin{array}{l}\text { Proximity to anthropic activities } \\
\text { (infrastructure) }\end{array}$ & & & & & & 20 \\
\hline Interest for mining & & & & & & 15 \\
\hline Site protection regime & & & & & & 15 \\
\hline Physical or indirect protection & & & & & & 15 \\
\hline Accessibility (potential assault) & & & & & & 15 \\
\hline Place ownership regime & & & & & & 10 \\
\hline Total & & 100 & 100 & 100 & 100 & 100 \\
\hline
\end{tabular}

Then, the total provides the value of $\mathrm{Si}, \mathrm{Di}$ and Ti. If the LIG exceeds 266 points, it is considered a place of "Very high" interest. Hence, the scores between 134 and 266 will be of "High" interest, and those lower than 134 points will be considered to be of "Medium" interest. The following equations are defined for the value of each interest:

$$
\begin{aligned}
S i & =\sum_{i=\text { parameter }}^{n \text { parameters }} \text { Puntuation } \times \text { Scientific weight } \\
D i & =\sum_{i=\text { parameter }}^{n \text { parameters }} \text { Puntuation } \times \text { Didactic weight } \\
T i & =\sum_{i=\text { parameter }}^{n \text { parameters }} \text { Puntuation } \times \text { Tourist weight }
\end{aligned}
$$


Furthermore, a qualitative evaluation about conservation of the site is achieved, where the Susceptibility of Degradation (SD) of the site is evaluated based on the Fragility (F) and the vulnerability due to anthropogenic Threats (T). With the SD, researchers can obtain the Protection Priority (PP) for Si, $\mathrm{Di}$, Ti of the LIG and rank the interests according to the PP value in its different vertices: scientific (SPP), didactic (DPP), touristic-recreation (TPP), and global (PP). Taking the threshold of the pilot project in the Iberian Cordillera [18] for a given value of the SD as reference, if the value is higher than 26, the PP degree "High" of the LIG. If the SD is equal to 26, the PP degree is "Medium". The "Medium-high" and "Medium-low" PP will be around 8. To obtain the values of fragility (F) and threat (T) that allow prioritizing and monitoring of the conservation status, where it is susceptible to degradation, and to quantify the priorities SPP, DPP, TPP, and PP, the researchers used the following equations:

$$
\begin{gathered}
F=\sum_{i=\text { parameter }}^{n \text { parameters }} \text { Puntuation } \times \text { Fragility weight } \\
T=\sum_{i=\text { parameter }}^{n \text { parameters }} \text { Puntuation } \times \text { Threat weight } \\
S D=((F \times T) \times 1 / 400) \\
S P P=\left(\left(S i^{2} \times S D\right) \times 1 / 400^{2}\right) \\
D P P=\left(\left(D i^{2} \times S D\right) \times 1 / 400^{2}\right) \\
T P P=\left(\left(T i^{2} \times S D\right) \times 1 / 400^{2}\right) \\
P P=[(S i+D i+T i) / 3]^{2} \times S D \times 1 / 400^{2}
\end{gathered}
$$

Moreover, the authors include a completed form of the proposed methodology that includes the Scientific, Didactic, Tourist and Popular Interest factors with Accessibility, Sensitivity and Conservation status (SDTPI-ASC), considering the 17 LIGs of relevant geological-paleontological importance. This approach strengthens the evaluated geological heritage. For this purpose, the interest categories are divided into Scientific interest (Si), Didactic interest (Di) and Touristic interest (Ti) and Popularization interest $(\mathrm{Pi})$, with its sections on accessibility to the place, sensitivity to plunder and current conservation status, as a basis for future studies.

\subsection{Third Phase: Strategies}

In this phase, based on expert judgment, the SWOT matrix configuration was done, with experiences from technical visits and studies in the Puyango Petrified Forest (BPP). This matrix allows establishing opportunities for geotourism development, identifying strengths, weaknesses and threats. The particular singularity of the territory in its geological and paleontological heritage has been highlighted, with a high interest for national and international geologists interested in investigating the geological record of the place, the scientific, educational and recreational use to strengthen the local economy.

There is a high fossil content, pleated structures, sedimentary, volcanic, metamorphic rocks with a natural, integral and biodiverse perspective, with samples of petrified trunks, pelecypods, macrofossils and ammonites. In the analysis of experts, the limitations or problems of the geosites are also considered, to turn them into new strategies for local development.

A SWOT analysis was carried out to assess the conservation status of the heritage site and to propose sustainable development strategies in a SWOT matrix [34], where the Puyango geopark project has great potential to promote the development of geotourism in the zone. 


\section{Results}

\subsection{Identification of the Pilot Area}

The identification of the pilot area includes the visit of the tourist trail carried out in the Puyango Petrified Forest (PPF), in the province of El Oro. This guided route lasts approximately $45 \mathrm{~min}$ and observation stops are made at the stations: (1) Lava flows, (2) Path of the Araucarias, that is a genus of evergreen coniferous trees in the family Araucariaceae, (3) Deposit of petrified logs, (4) Carboniferous zones, (5) Path of the Giant, and (6) Giant Petrine (Figure 4).

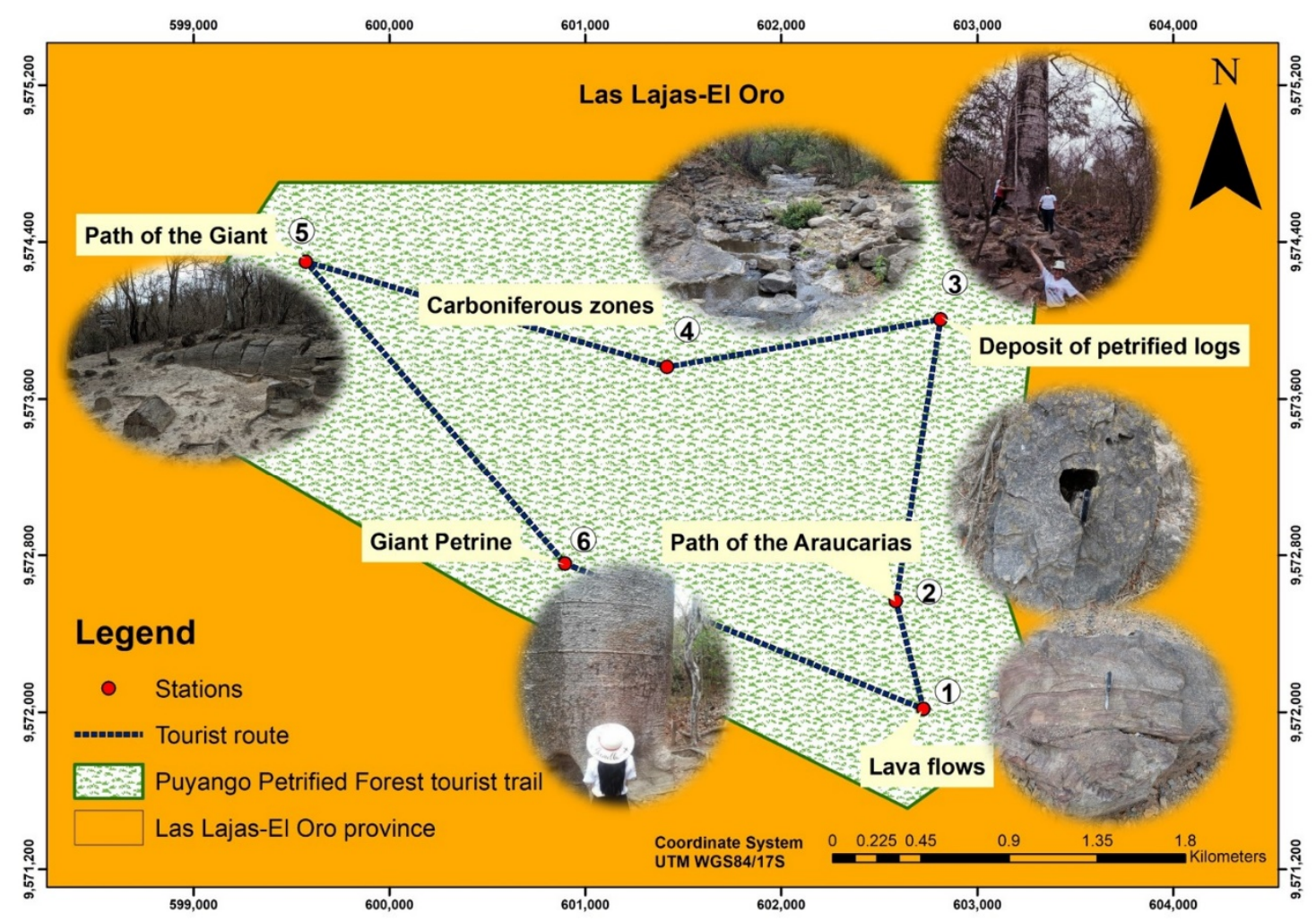

Figure 4. Map of the Puyango Petrified Forest tourist trail, El Oro Province [28].

For a better scientific reference about LIGs, Table 2 details the important geological aspects such as geological structures and type of rocks found in the geosite, as well as paleontological aspects that stand out for their fossil content, the type of fossilization and the number of petrified trunks found in each geosite which makes it an excellent geotouristic remnant.

Some of the LIGs mentioned in Table 2 belong to the province of El Oro, such as the streams Sábalos, Las Palmas, El Tigre, El Guineo, El Gringo, Quemazón and in the province of Loja are the El Chirimoyo, Cochurco, El Limón, Las Concreciones and Tunima (Figure 5). In the Cochurco, El Chirimoyo and Las Concreciones streams, remains of mollusk shell molds such as pelecypods and ammonites have been found in the limestones [26]. 
Table 2. Geological and paleontological aspects of the LIGs.

\begin{tabular}{|c|c|c|c|c|}
\hline $\mathbf{N}^{\circ}$ & LIGs & Geological Aspects & Paleontological Aspects & Observations \\
\hline 1 & PPF Tourist trail & Volcano-sedimentary rocks. & $\begin{array}{l}\text { It contains abundant } \\
\text { remains of well-preserved } \\
\text { petrified trunks. }\end{array}$ & $\begin{array}{l}\text { It is a guided tourist route } \\
\text { in the tropical dry forest } \\
\text { (fauna and flora). }\end{array}$ \\
\hline 2 & Sábalos stream & $\begin{array}{l}\text { Geological domain: Alamor, } \\
\text { Lancones Basin. At the base, } \\
\text { some ortho-quartzites and } \\
\text { conglomerates rest } \\
\text { discordantly on the } \\
\text { Amotape, Tahuin massif. } \\
\text { Black marl, massive layers of } \\
\text { limestone and banded black } \\
\text { shales, clays, siltstones and } \\
\text { sandstones with lava and } \\
\text { sedimentary volcano rocks. }\end{array}$ & $\begin{array}{l}\text { It contains abundant } \\
\text { remains of petrified trunks } \\
\text { corresponding to } \\
\text { Araucariaceas. }\end{array}$ & $\begin{array}{l}\text { The trunks are well } \\
\text { preserved, practically } \\
\text { intact of large dimensions, } \\
\text { the only fossil specimens } \\
\text { resulting from the } \\
\text { fossilization process of } \\
\text { petrification, product of } \\
\text { the replacement of organic } \\
\text { matter by silica. }\end{array}$ \\
\hline 3 & Cochurco stream & $\begin{array}{l}\text { Volcanic materials and } \\
\text { sedimentary limestones } \\
\text { and shales. }\end{array}$ & $\begin{array}{l}\text { Remains of fossil roots } \\
\text { (charred), remains of } \\
\text { petrified trunks. Fossil } \\
\text { invertebrates, present as } \\
\text { internal and } \\
\text { external moulds. }\end{array}$ & $\begin{array}{l}\text { A petrified trunk of } \\
\text { Araucariaceas well } \\
\text { preserved, in a significant } \\
\text { vertical position. }\end{array}$ \\
\hline 4 & Chirimoyo stream & $\begin{array}{l}\text { Geological deformations } \\
\text { (folds) in sedimentary rocks } \\
\text { represented by clay. }\end{array}$ & $\begin{array}{l}\text { Remains of fossil } \\
\text { invertebrates: Pelecypods, } \\
\text { Inoceramus and Ammonites; } \\
\text { and microfossils: planktonic } \\
\text { and benthic foraminifera, } \\
\text { calcareous nanofossils and } \\
\text { Palinomorphs. }\end{array}$ & $\begin{array}{l}\text { Invertebrate marine fauna } \\
\text { is very frequent. }\end{array}$ \\
\hline 5 & El Limón stream & $\begin{array}{l}\text { Geological deformations, } \\
\text { fold (anticline) in } \\
\text { volcano-sedimentary rocks. } \\
\text { Calcareous rocks } \\
\text { (Coquina type). }\end{array}$ & $\begin{array}{l}\text { Petrified trunks well } \\
\text { preserved. Invertebrate } \\
\text { fossils: foraminifera and } \\
\text { calcareous nanofossils. }\end{array}$ & $\begin{array}{l}\text { Petrified (carbonized) } \\
\text { trunks, in which the } \\
\text { cellulose of the trees was } \\
\text { transformed into } \\
\text { anthracite due to the loss } \\
\text { of methane, water and } \\
\text { carbon dioxide. } \\
\text { This geosite has a potential } \\
\text { area to recreation (crystal } \\
\text { clear lagoon). }\end{array}$ \\
\hline 6 & El Guineo stream & $\begin{array}{l}\text { It shows stratifications by } \\
\text { the alternative deposit of } \\
\text { sediments of different } \\
\text { composition. }\end{array}$ & $\begin{array}{l}\text { Fossil invertebrates: a } \\
\text { phylum of molluscs, bivalves } \\
\text { and ammonites and } \\
\text { petrified trunks. }\end{array}$ & Pelecypod prints. \\
\hline 7 & Gringo Beach & $\begin{array}{l}\text { Volcano-sedimentary rocks, } \\
\text { limestones, shales and clays. }\end{array}$ & $\begin{array}{l}\text { Fossil invertebrates: a } \\
\text { phylum of molluscs, } \\
\text { bivalves and ammonites. }\end{array}$ & $\begin{array}{l}\text { Vegetable fossil remains, } \\
\text { from fossilization } \\
\text { processes (carbonization). }\end{array}$ \\
\hline 8 & Las Concreciones stream & $\begin{array}{l}\text { Limestone outcrop } \\
\text { associated with a core of } \\
\text { Ammonites. Shales, marls } \\
\text { and thin layers of clays. The } \\
\text { limestones inside have } \\
\text { pyrite. }\end{array}$ & $\begin{array}{l}\text { Ammonite concretions. } \\
\text { Molluscs, foraminifera and } \\
\text { calcareous nanofossils and } \\
\text { ostracods. }\end{array}$ & $\begin{array}{l}\text { A unique geosite: can be } \\
\text { shown calcareous } \\
\text { concretions. }\end{array}$ \\
\hline 9 & Las Palmas stream & Volcano-sedimentary rocks. & $\begin{array}{l}\text { Remains of allochthonous } \\
\text { petrified trunks. }\end{array}$ & $\begin{array}{l}\text { Little diversity of petrified } \\
\text { trunks. }\end{array}$ \\
\hline 10 & Quemazón stream & $\begin{array}{l}\text { Geological deformations, } \\
\text { folding and thrust in } \\
\text { limestone rocks. }\end{array}$ & $\begin{array}{l}\text { Appears a few remains of } \\
\text { petrified (charred) trunks. }\end{array}$ & $\begin{array}{l}\text { Fossilization processes } \\
\text { (carbonization). }\end{array}$ \\
\hline 11 & Tunima stream & $\begin{array}{l}\text { Volcano-clastic rocks, with } \\
\text { levels containing } \\
\text { petrified trunks. }\end{array}$ & $\begin{array}{l}\text { Petrified trunks } \\
\text { well preserved. }\end{array}$ & $\begin{array}{l}\text { Petrified trunk in } \\
\text { volcano-clastic rocks with } \\
\text { a diameter smaller than } \\
\text { found in Sábalos and } \\
\text { Chocurco streams. }\end{array}$ \\
\hline 12 & Puyango River course & $\begin{array}{l}\text { Geographical reference } \\
\text { whose cause has an altitude } \\
\text { of } 200 \text { m.a.s.l, is the water } \\
\text { axis of importance for the } \\
\text { ENE-WSW direction } \\
\text { according to the structural } \\
\text { limits of the sector. }\end{array}$ & $\begin{array}{l}\text { Allochthonous } \\
\text { petrified trunks. }\end{array}$ & $\begin{array}{l}\text { Appears remains of } \\
\text { petrified trunks and } \\
\text { fossil invertebrates. }\end{array}$ \\
\hline
\end{tabular}


Table 2. Cont.

\begin{tabular}{cllll}
\hline $\mathbf{N}^{\circ}$ & \multicolumn{1}{c}{ LIGs } & \multicolumn{1}{c}{ Geological Aspects } & Paleontological Aspects & Observations \\
\hline 13 & Puyango, Alamor trail & None. & $\begin{array}{l}\text { Allochthonous } \\
\text { petrified trunks. }\end{array}$ & None. \\
\hline 14 & El Tigre stream & $\begin{array}{l}\text { Volcano-sedimentary } \\
\text { sediments reddish color due } \\
\text { to the presence of } \\
\text { iron oxides. }\end{array}$ & $\begin{array}{l}\text { Vegetable fossil remains } \\
\text { (fossilized leaf) by } \\
\text { fossilization processes } \\
\text { (carbonization) }\end{array}$ & $\begin{array}{l}\text { The only geosite with a } \\
\text { petrified leaf specimen in } \\
\text { the fossilization process } \\
\text { (carbonization). }\end{array}$ \\
\hline \multirow{2}{*}{15} & La Libertad fold & $\begin{array}{l}\text { Metamorphic deformations. } \\
\text { Anticline fold. }\end{array}$ & $\begin{array}{l}\text { Geosite without } \\
\text { paleontological remains. }\end{array}$ & $\begin{array}{l}\text { Geological deformations } \\
\text { due to } \\
\text { compressive stresses. }\end{array}$ \\
\hline 16 & Playón Las Pailas & $\begin{array}{l}\text { Appears deposits of visible } \\
\text { material of sedimentary } \\
\text { rocks along the river bed in } \\
\text { the dry season. }\end{array}$ & $\begin{array}{l}\text { Sedimentary rocks } \\
\text { carbonated, with remains of } \\
\text { invertebrates. }\end{array}$ & $\begin{array}{l}\text { Recreational tourist place } \\
\text { for organized activities. }\end{array}$ \\
\hline & PPF Interpretation left & $\begin{array}{l}\text { Exists geological } \\
\text { information (samples of } \\
\text { rocks and } \\
\text { calcareous concretions). }\end{array}$ & $\begin{array}{l}\text { Petrified trunks, fossils. } \\
\text { Recreation area, location } \\
\text { maps of the main gorges, } \\
\text { paleontological information. }\end{array}$ & Disclosure area. \\
\hline
\end{tabular}

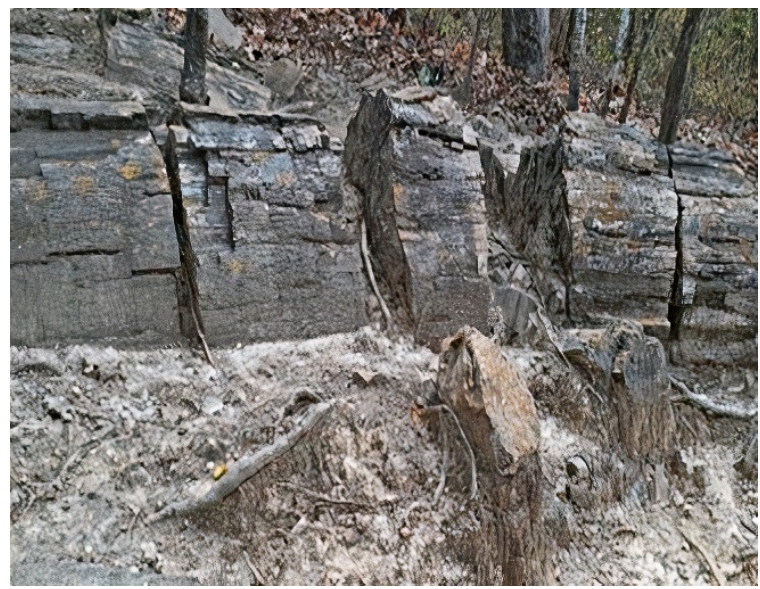

(a)

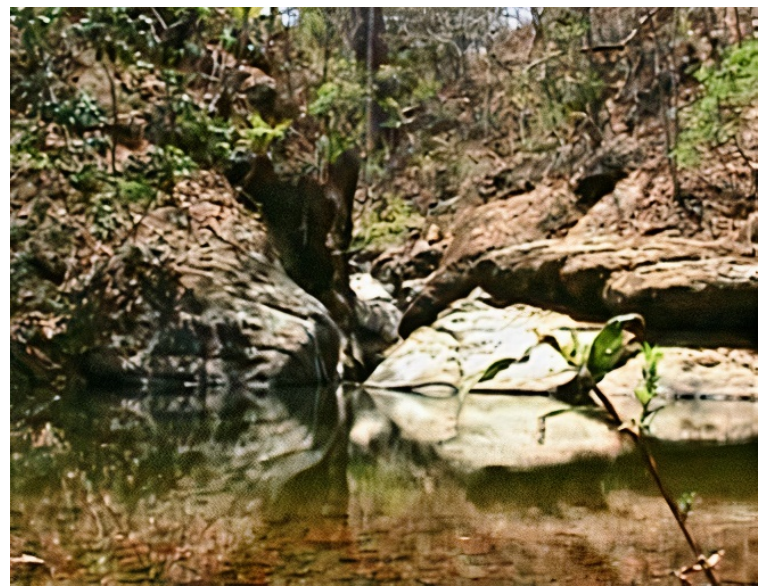

(c)

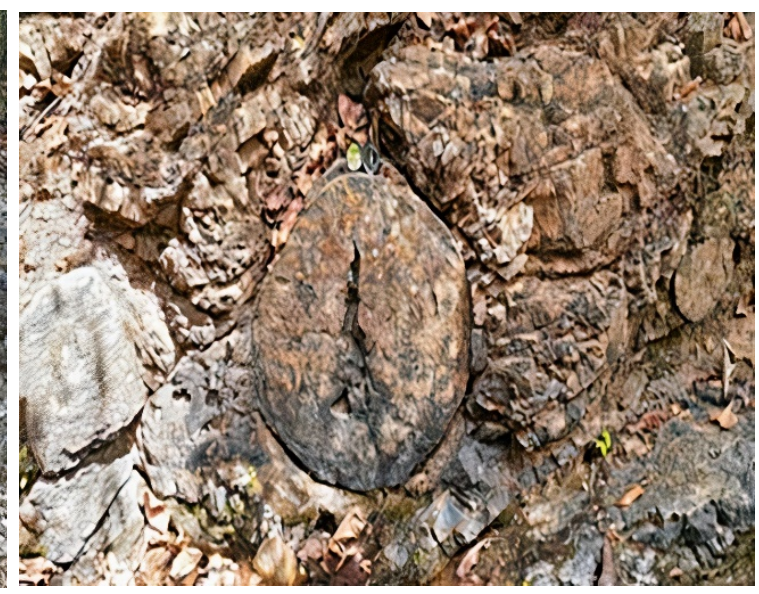

(b)

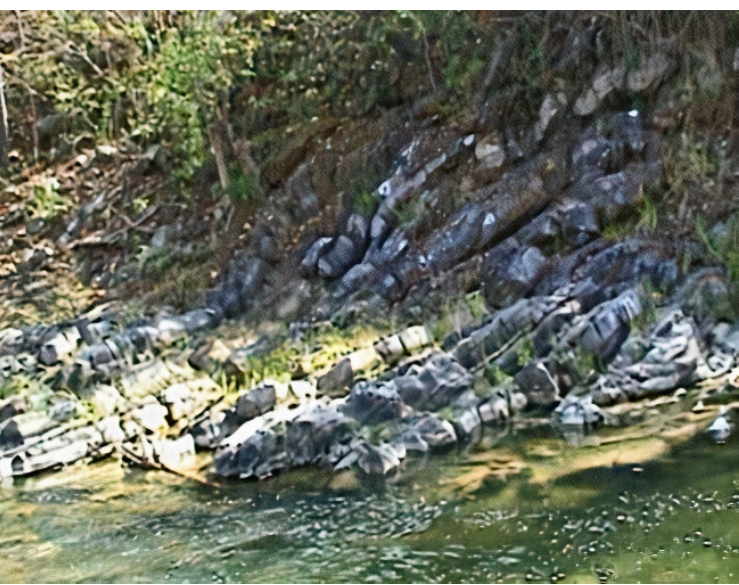

(d)

Figure 5. Streams of the province of El Oro (a) Sábalos, (b) Cochurco, (c) Las Palmas and (d) Las Concreciones.

Moreover, a stratigraphic column of the Las Concreciones stream is shown (Figure 6) as a result of the scientific research carried out in. The stream adopted that name because at the beginning of the stream, precisely upstream, there are concretions of limestone rolled from the upper part, 
whose outcrop is made of sedimentary material. On the shales, limestones, marls and thin layers of clay are observed. Limestone concretions of $0.80 \mathrm{~m}$ in diameter are observed in the rock with a light gray hue. The limestones are crystalline with pyrite as a mineral. In addition, the concretion of two Ammonite molds lie, and a large limestone outcrop approximately $7 \mathrm{~m}$ thick stands out at the end of the station [27].

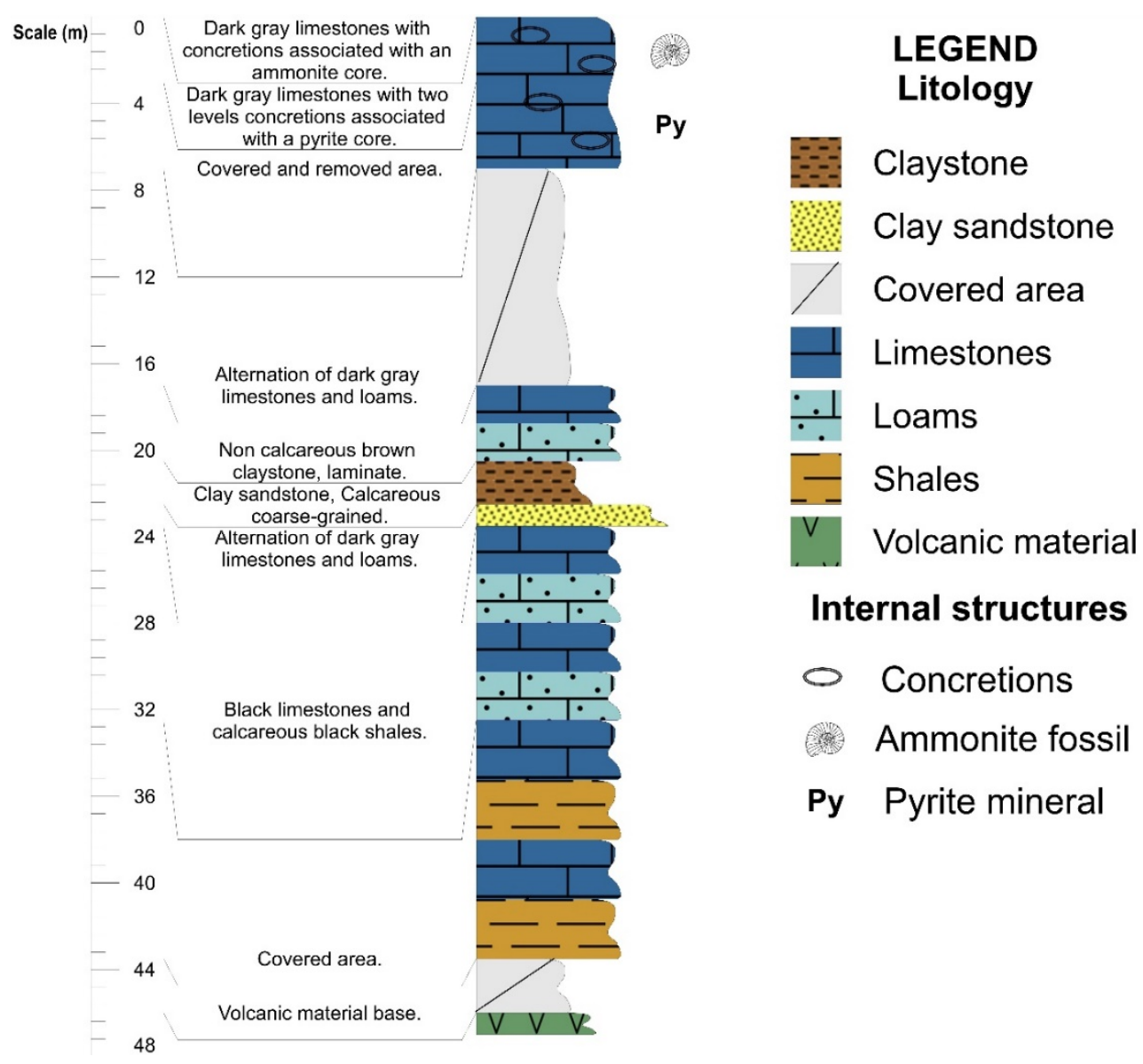

Figure 6. Stratigraphic Column of the Las Concreciones stream. Modified from [29].

The fossil invertebrates are marine and belong to the pelecypods and cephalopod classes of mollusks (Figure 7). The cephalopod class is represented by ammonoids represented by the internal and external molds as well as petrified shells in the Cochurco, El Chirimoyo, El Limón, Las Concreciones, and El Guineo streams. The internal molds of mollusks with Nucula spp, Inoceramus concentricus, Astarte spp and Heterodontido (See Supplementary Figures S1-S4) [26]. 

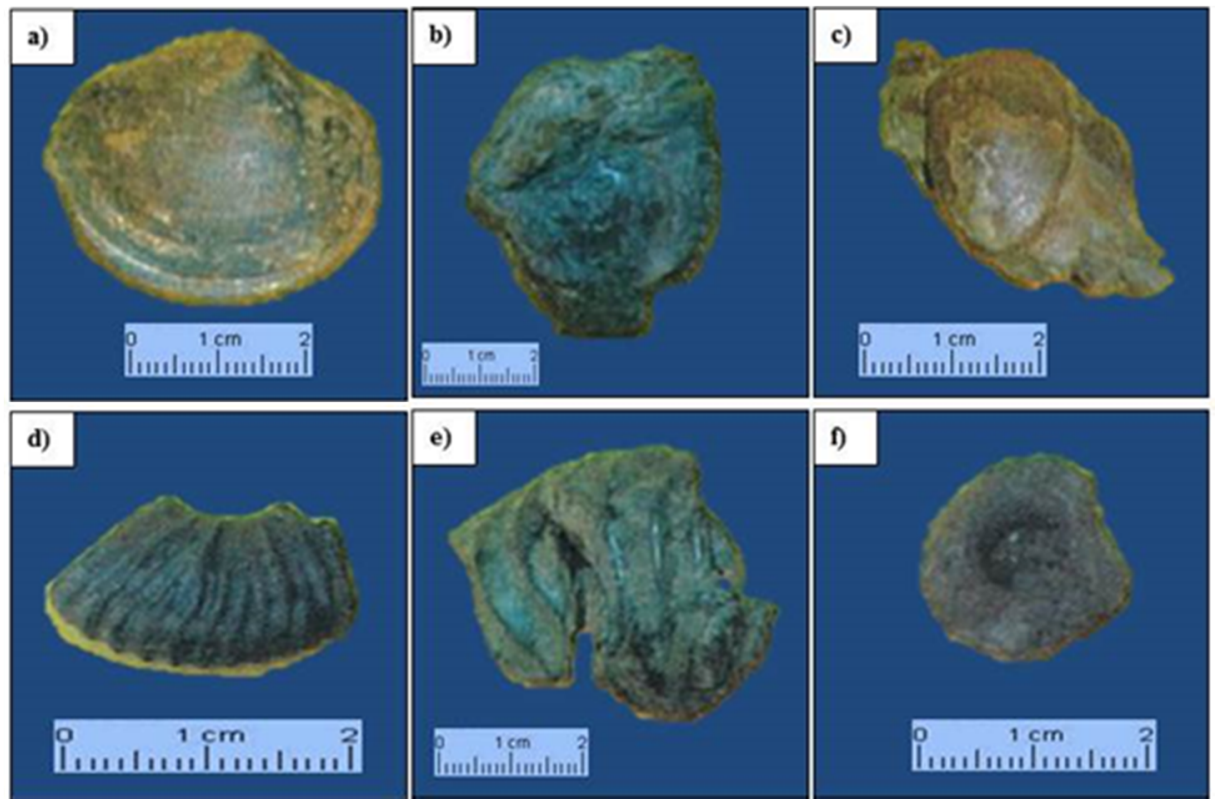

Figure 7. Macro-fossils in the province of Loja: (a) Pelecipodo heterodontido, (b) Ostrea sp., (c) Astarte sp., (d) Peltoceras sp., (e) Fragment of return of Ammonitido and (f) Schoenbachia sp.

\subsection{Evaluation}

The results of phase ii with the scientific, didactic and touristic interests are presented according to the IELIG methodology with its justification in Table 3.

To obtain the value of each item of interest, Equations (1)-(3) were used. Results reveal that the Puyango Petrified Forest presents a "Very high" and "High" global degree of interest in the Scientific (Si), Didactic (Di) and Touristic (Ti) aspects. Although some of them have a "Middle" public interest (Figure 8), the reason is that the lack of strategies that promote the geodiversity of the area through geotourism.

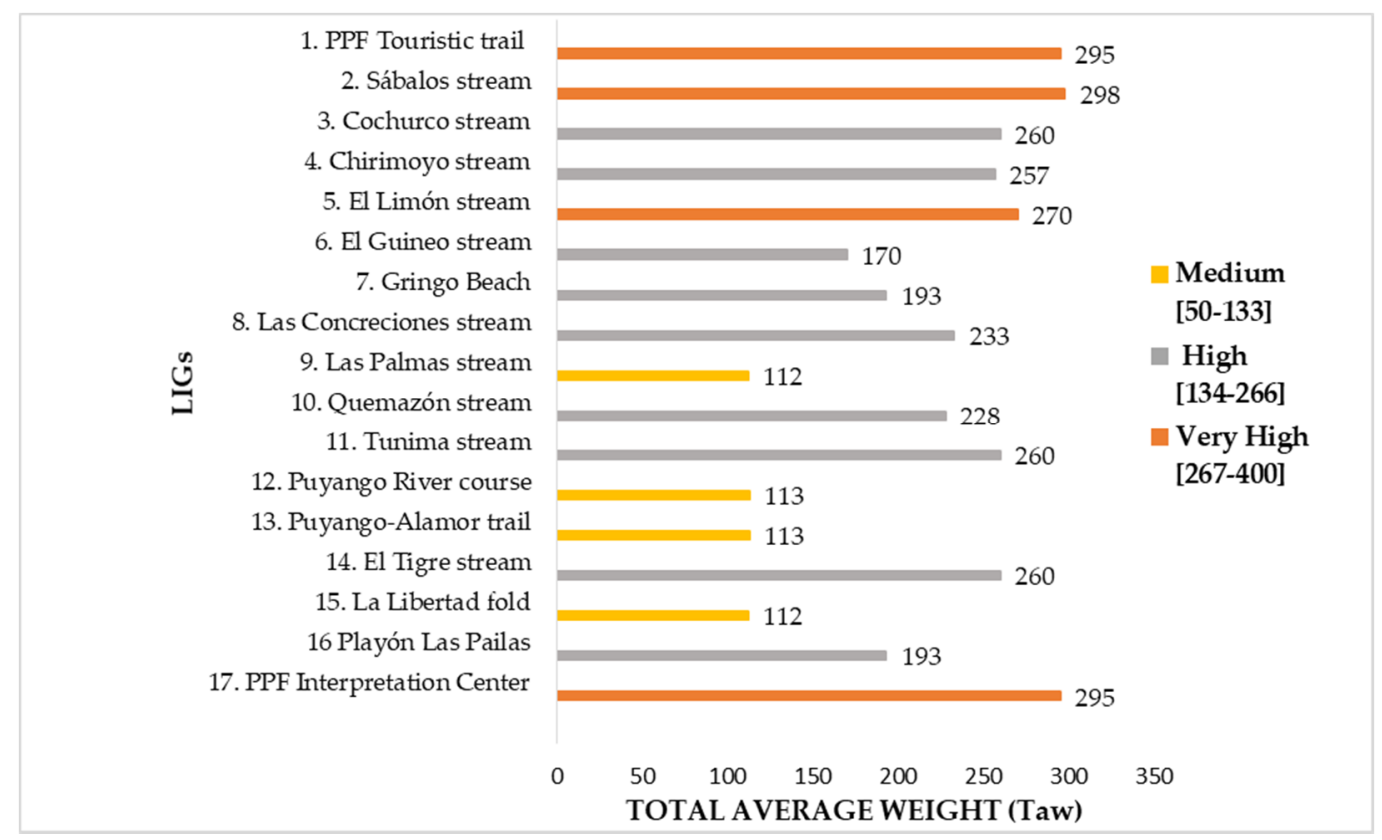

Figure 8. Assessment of the degree of geological interest of the LIGs in the Puyango Petrified Forest according to IELIG. 
Table 3. Description of the main indicators evaluated by the IELIG methodology.

\begin{tabular}{|c|c|c|}
\hline Value & Indicators/Parameters & Description \\
\hline \multirow{7}{*}{ Scientific value } & Representativeness & $\begin{array}{l}\text { The Puyango Petrified Forest (PPF) is a } \\
\text { source of knowledge and well-being and } \\
\text { it is the unique place with the best } \\
\text { paleontological exposure in Ecuador. The } \\
\text { area shows a sequence of } \\
\text { volcano-sediment from the Cretaceous age } \\
\text { (Albian-Middle). A collection of petrified } \\
\text { trunks, fossilized leaves of common } \\
\text { gymnosperms and remains of mollusk } \\
\text { shell molds of the Southern Cretaceous } \\
\text { have been found in PPF deposits. }\end{array}$ \\
\hline & $\begin{array}{l}\text { Prototype location } \\
\text { character }\end{array}$ & $\begin{array}{l}\text { PPF is a site of geological interest and a } \\
\text { good example of a paleontological deposit, } \\
\text { where specimens of petrified trunks and } \\
\text { other allochthonous from Aptian-Middle } \\
\text { and Jurassic-Cretaceous are found in situ. }\end{array}$ \\
\hline & $\begin{array}{l}\text { Degree of scientific } \\
\text { knowledge of the place }\end{array}$ & $\begin{array}{l}\text { There are several works published in } \\
\text { national and international journals } \\
\text { performed by geoscientists and theses } \\
\text { carried out by students and professionals } \\
\text { on geological, paleontological, } \\
\text { archaeological, botanical, cultural, } \\
\text { economic and tourism topics. }\end{array}$ \\
\hline & State of conservation & $\begin{array}{l}\text { PPF presents a regular state of } \\
\text { conservation. Some deteriorated areas } \\
\text { prevent the observation of geological } \\
\text { characteristics (landslides). Some } \\
\text { information panels are } \\
\text { partially deteriorated. }\end{array}$ \\
\hline & Observation conditions & $\begin{array}{l}\text { The observation of several silicified trunks } \\
\text { of Araucariaceas and Metapodocarpoxylon } \\
\text { specimens, marine invertebrate fossils of } \\
\text { the phylum Mollusca of the pelecypods } \\
\text { class and cephalopod (ammonoids) } \\
\text { possible. The fossilized flora corresponds } \\
\text { to the subphylum of the mid-Mesozoic } \\
\text { gymnosperms of the Zamites, Dioonites, } \\
\text { Nilssonia, Otozamites, Podozamites, Carpites, } \\
\text { and other genera. It is also a dry-tropical } \\
\text { forest ecosystem that preserves species } \\
\text { (fauna and flora) existing today. }\end{array}$ \\
\hline & Rarity & $\begin{array}{l}\text { The petrified trunks of Puyango represent } \\
\text { one of the largest collections of petrified } \\
\text { wood in Ecuador and probably in the } \\
\text { world. The site has unique characteristics } \\
\text { from the Cretaceous Period. }\end{array}$ \\
\hline & Geological diversity & $\begin{array}{l}\text { The paleontological aspect stands out as } \\
\text { the main geological interest, followed by } \\
\text { the stratigraphic, sedimentological, } \\
\text { structural and geological history. } \\
\text { Secondary features are the } \\
\text { historical/archaeological, biodiversity, } \\
\text { cultural and landscape. }\end{array}$ \\
\hline
\end{tabular}


Table 3. Cont.

\begin{tabular}{|c|c|c|}
\hline Value & Indicators/Parameters & Description \\
\hline \multirow{9}{*}{$\begin{array}{l}\text { Educational potential } \\
\text { and touristic use }\end{array}$} & Didactic content & $\begin{array}{l}\text { Educational visits and excursions from } \\
\text { schools, colleges, and universities take } \\
\text { place considering the protection of the } \\
\text { geological-paleontological heritage of the } \\
\text { place. }\end{array}$ \\
\hline & Logistics infrastructure & $\begin{array}{l}\text { It lacks nearby accommodations and } \\
\text { restaurants for tourist groups, but it has } \\
\text { an interpretation and information left for } \\
\text { tourists. }\end{array}$ \\
\hline & Accessibility & $\begin{array}{l}\text { Using a national highway there is the } \\
\text { access } \\
\text { Guayaquil-Machala-Arenillas-Puyango } \\
\text { with a } 276 \mathrm{~km} \text { route. From Huaquillas } \\
\text { (border with Peru), there are } 62 \mathrm{~km} \text {. } \\
\text { Another access road goes from } \\
\text { Loja-Veracruz- Catacocha's city through a } \\
\text { state highgway and then El } \\
\text { Empalme-Celica-Alamor-Puyango with a } \\
\text { distance of } 213 \mathrm{~km}[26] \text {. }\end{array}$ \\
\hline & $\begin{array}{l}\text { Association with other } \\
\text { elements of the natural } \\
\text { and/or cultural heritage }\end{array}$ & $\begin{array}{l}\text { Numerous archaeological remains } \\
\text { (petroglyphs) found in different parts of } \\
\text { the Puyango canton. }\end{array}$ \\
\hline & Magnificence or beauty & $\begin{array}{l}\text { Landscape, river course, remains of plant } \\
\text { fossils and invertebrates as evidence of } \\
\text { ancient times. }\end{array}$ \\
\hline & $\begin{array}{l}\text { Informative } \\
\text { content/Informative use } \\
\text { detected }\end{array}$ & $\begin{array}{l}\text { Limited and without a tourist information } \\
\text { department. }\end{array}$ \\
\hline & $\begin{array}{l}\text { Potential to carry out } \\
\text { touristic and recreational } \\
\text { activities }\end{array}$ & $\begin{array}{l}\text { It has touristic trails, fossil deposits } \\
\text { and streams. }\end{array}$ \\
\hline & $\begin{array}{l}\text { Proximity to recreational } \\
\text { areas (immediate } \\
\text { potential demand) }\end{array}$ & $\begin{array}{l}\text { There is a camping area less than } 500 \mathrm{~m} \\
\text { from the forest. }\end{array}$ \\
\hline & $\begin{array}{l}\text { Socioeconomic } \\
\text { environment }\end{array}$ & $\begin{array}{l}\text { The most common economic activities are } \\
\text { the short cycle crops sowing and coffee, } \\
\text { cattle and pig raising. }\end{array}$ \\
\hline \multirow{3}{*}{ Fragility } & LIG size & Area of 2.6 ha. with 17 LIGs. \\
\hline & Vulnerability to plunder & $\begin{array}{l}\text { A paleontological site of great value, with } \\
\text { numerous specimens and easy plunder. }\end{array}$ \\
\hline & Natural threats & $\begin{array}{l}\text { Possible landslides, flooding of rivers, } \\
\text { weakening of the soil and climatic } \\
\text { variations due to severe droughts. }\end{array}$ \\
\hline
\end{tabular}


Table 3. Cont.

\begin{tabular}{|c|c|c|}
\hline Value & Indicators/Parameters & Description \\
\hline \multirow{7}{*}{$\begin{array}{l}\text { Vulnerability due to } \\
\text { anthropogenic threats }\end{array}$} & $\begin{array}{l}\text { Proximity to anthropic } \\
\text { activities (infrastructure) }\end{array}$ & Place not threatened. \\
\hline & Interest for mining & No mining interest in the area. \\
\hline & Site protection regime & $\begin{array}{l}\text { Cultural Heritage, Ordinance for the } \\
\text { Declaration of the Bi-provincial Protected } \\
\text { Area, in the Category of Ecological } \\
\text { Conservation Area. }\end{array}$ \\
\hline & $\begin{array}{l}\text { Physical or indirect } \\
\text { protection }\end{array}$ & Protected area with access to tourists. \\
\hline & $\begin{array}{l}\text { Accessibility } \\
\text { (potential assault) }\end{array}$ & $\begin{array}{l}\text { It is directly accessible through unpaved } \\
\text { and passable track for tourism. }\end{array}$ \\
\hline & Place ownership regime & $\begin{array}{l}\text { Location in restricted access areas } \\
\text { declared as natural heritage. }\end{array}$ \\
\hline & $\begin{array}{l}\text { Population density } \\
\text { (potential aggression) }\end{array}$ & $\begin{array}{l}\text { The town is located at the entrance to the } \\
\text { forest tourist complex that belongs to the } \\
\text { province of El Oro, Las Lajas canton. } \\
\text { It has an economically active population } \\
\text { of approximately } 200 \text { people, mostly } \\
\text { farmers [26]. }\end{array}$ \\
\hline
\end{tabular}

The results of the applied evaluation of the IELIG methodology are represented in Table 4, noting that there are four LIGs with Geological Interest (IG) "Very High", nine of interest "High" and four "Medium", reflecting the great relevance of the Puyango Petrified Forest. The Global Protection Priority (PPG) values are also shown, finding most of the LIGs with the rating of "Medium-low".

The fossilized trunks resulted from the fossilization process, especially petrification by replacing organic matter such as cellulose and limenine with silica [33,35]. The paleontological importance with the highest concentration of logs has been found in the old Puyango-Alamor highway and El Chirimoyo, El Limón, and Cochurco streams, where specimens of logs of up to $26 \mathrm{~m}$ long by $2.2 \mathrm{~m}$ in diameter have been located (Figure 9).

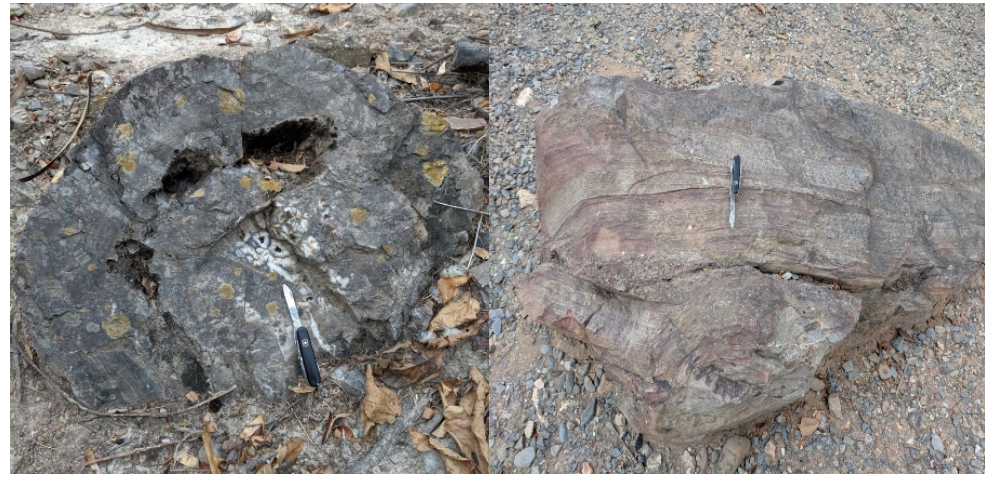

(a)

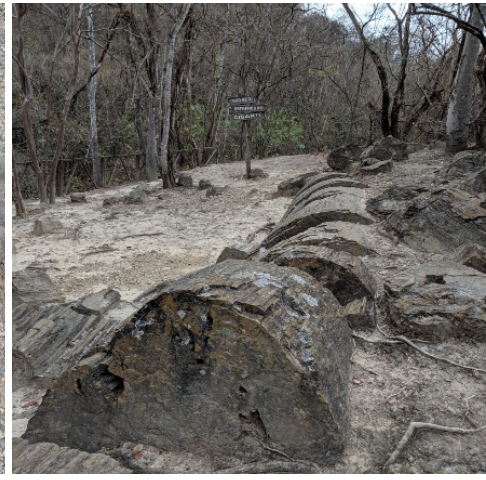

(c)

Figure 9. (a,b) Logs petrified with silica. (c) Giant petrified trunk. 
Table 4. Quantitative assessment of parameters Scientific interest (Si), Didactic interest (Di), Touristic interest (Ti), Total Average Weight (Taw), Degree of geological interest (GI), Susceptibility of Degradation (SD), Scientific Protection Priority (SPP), Didactic Protection Priority (DPP), Touristic Protection Priority (TPP), Protection Priority (PP) and Global Protection Priority (PPG), according to the IELIG methodology.

\begin{tabular}{|c|c|c|c|c|c|c|c|c|c|c|c|c|}
\hline $\mathbf{N}^{\circ}$ & LIGs & Si & Di & Ti & Taw & GI & SD & SPP & DPP & TPP & PP & PPG \\
\hline 1 & $\begin{array}{l}\text { PPF Touristic } \\
\text { trail }\end{array}$ & 380 & 275 & 230 & 295 & Very High & 50 & 45.13 & 23.63 & 16.53 & 27.20 & High \\
\hline 2 & Sábalos stream & 360 & 250 & 285 & 298 & Very High & 4.50 & 3.65 & 1.76 & 2.28 & 2.50 & Medium-low \\
\hline 3 & $\begin{array}{l}\text { Cochurco } \\
\text { stream }\end{array}$ & 320 & 225 & 235 & 260 & High & 8.25 & 5.28 & 2.61 & 2.85 & 3.49 & Medium-low \\
\hline 4 & $\begin{array}{l}\text { Chirimoyo } \\
\text { stream }\end{array}$ & 330 & 215 & 225 & 257 & High & 18 & 12.25 & 5.20 & 5.69 & 7.41 & Medium-low \\
\hline 5 & $\begin{array}{l}\text { El Limón } \\
\text { stream }\end{array}$ & 335 & 215 & 260 & 270 & High & 0 & 0 & 0 & 0 & 0 & Medium-low \\
\hline 6 & $\begin{array}{l}\text { El Guineo } \\
\text { stream }\end{array}$ & 185 & 150 & 175 & 170 & High & 0 & 0 & 0 & 0 & 0 & Medium-low \\
\hline 7 & Gringo Beach & 240 & 165 & 175 & 193 & High & 9.75 & 3.15 & 1.66 & 1.87 & 2.27 & Medium-low \\
\hline 8 & $\begin{array}{c}\text { Las } \\
\text { Concreciones } \\
\text { stream }\end{array}$ & 270 & 175 & 255 & 233 & High & 5.63 & 2.56 & 1.08 & 2.29 & 1.91 & Medium-low \\
\hline 9 & $\begin{array}{l}\text { Las Palmas } \\
\text { stream }\end{array}$ & 110 & 80 & 145 & 112 & Medium & 9 & 0.68 & 0.36 & 1.18 & 0.70 & Medium-low \\
\hline 10 & $\begin{array}{l}\text { Quemazón } \\
\text { stream }\end{array}$ & 305 & 170 & 210 & 228 & High & 0 & 0 & 0 & 0 & 0 & Medium-low \\
\hline 11 & Tunima stream & 320 & 225 & 235 & 260 & High & 8.25 & 5.28 & 2.61 & 2.85 & 3.49 & Medium-low \\
\hline 12 & $\begin{array}{l}\text { Puyango River } \\
\text { course }\end{array}$ & 110 & 90 & 140 & 113 & Medium & 82.50 & 6.24 & 4.18 & 10.11 & 6.62 & Medium-low \\
\hline 13 & $\begin{array}{l}\text { Puyango-Alamor } \\
\text { trail }\end{array}$ & 110 & 90 & 140 & 113 & Medium & 82.50 & 6.24 & 4.18 & 10.11 & 6.62 & Medium-low \\
\hline 14 & El Tigre stream & 320 & 225 & 235 & 260 & High & 8.25 & 5.28 & 2.61 & 2.85 & 3.49 & Medium-low \\
\hline 15 & $\begin{array}{l}\text { La Libertad } \\
\text { fold }\end{array}$ & 110 & 80 & 145 & 112 & Medium & 9 & 0.68 & 0.36 & 1.18 & 0.70 & Medium-low \\
\hline 16 & $\begin{array}{l}\text { Playón Las } \\
\text { Pailas }\end{array}$ & 240 & 165 & 175 & 193 & High & 9.75 & 3.15 & 1.66 & 1.87 & 2.27 & Medium-low \\
\hline 17 & $\begin{array}{c}\text { PPF } \\
\text { Interpretation } \\
\text { Center }\end{array}$ & 380 & 275 & 230 & 295 & Very High & 50 & 45.13 & 23.63 & 16.53 & 27.20 & High \\
\hline
\end{tabular}

From the point of view of the conservation of LIG, it is necessary to determine the susceptibility of degradation. This analysis is performed through the fragility and natural threats components. Hence, mitigation actions can be taken to reduce as far as possible the vulnerability of the geosite and the damage caused by an event and anthropic threats identified in the sector. The data obtained as a result of the implementation of Equations (6)-(10) were presented in Table 4. With this values, Protection priorities "Medium-low" were identified for each of the protection priority parameters SPP, DPP, TPP and PP, which depend on the value calculated in the LIG Degradation Susceptibility (SD), this parameter is calculated independently of the others. The Figure 10 shows the sections of SPP, DPP and TPP with a global Protection Priority (PP) "Medium-low", except for two LIGs with a PP "High". 


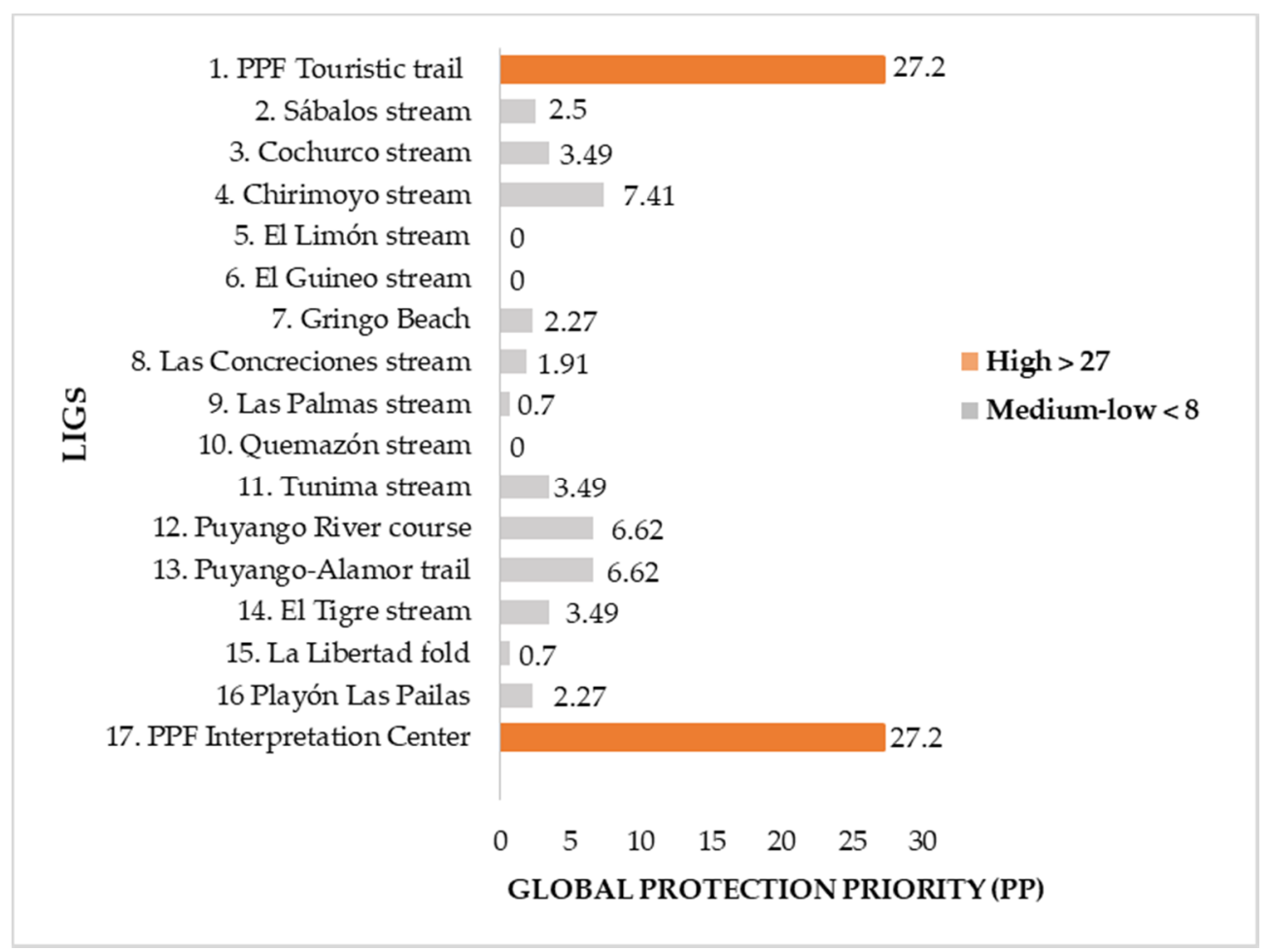

Figure 10. Assessment of the Protection Priority of the LIGs.

Additionally, all 17 LIGs which strengthen the entire system of geological-paleontological heritage in this sector are marked in the PPF. With the application of the Scientific, Didactic, Tourist and Popular Interest with Accessibility, Sensitivity and Conservation Status methodology (SDTPI-ASC), the authors identified the different types of interest: Scientific (Si), Didactic (Di), Tourist (Ti) and Popularization (Pi). The SDTPI-ASC was supported by the criteria of experts Nelson Jiménez, Jorge Marcos and Irina Xomchuk, based on [26]; Table 5 illustrates the SDTPI-ASC methodology.

Table 5. Referential assessment of the LIGs by the SDTPI-ASC methodology evaluated by experts in the Puyango Petrified Forest. It has a type of interest $(\checkmark)$.

\begin{tabular}{|c|c|c|c|c|c|c|c|c|c|}
\hline \multirow{2}{*}{$\mathbf{N}^{\circ}$} & \multirow{2}{*}{ LIGs } & \multirow{2}{*}{$\begin{array}{c}\text { UTM } \\
\text { Coordinates }\end{array}$} & \multicolumn{4}{|c|}{ Type of Interest } & \multirow{2}{*}{ Accessibility } & \multirow{2}{*}{ Sensitivity } & \multirow{2}{*}{$\begin{array}{c}\text { Conservation } \\
\text { Status }\end{array}$} \\
\hline & & & $\mathrm{Si}$ & Di & Ti & $\mathbf{P i}$ & & & \\
\hline 1 & $\begin{array}{l}\text { PPF Tourist } \\
\text { trail }\end{array}$ & $\begin{array}{l}\text { 601735E, } \\
9560324 S\end{array}$ & $\checkmark$ & $\checkmark$ & $\checkmark$ & $\checkmark$ & Good & Average & Good \\
\hline 2 & Sábalos stream & $\begin{array}{l}\text { 602734E, } \\
9570326 \mathrm{~S}\end{array}$ & $\checkmark$ & $\checkmark$ & $\checkmark$ & $\checkmark$ & Good & Average & Good \\
\hline 3 & $\begin{array}{l}\text { Cochurco } \\
\text { stream }\end{array}$ & $\begin{array}{l}606966 \mathrm{E}, \\
9572143 \mathrm{~S}\end{array}$ & $\checkmark$ & $\checkmark$ & $\checkmark$ & $\checkmark$ & Good & Poor & Good \\
\hline 4 & $\begin{array}{c}\text { Chirimoyo } \\
\text { stream }\end{array}$ & $\begin{array}{l}\text { 603047E, } \\
9563869 S\end{array}$ & $\checkmark$ & $\checkmark$ & $\checkmark$ & & $\begin{array}{c}\text { Below } \\
\text { average }\end{array}$ & Poor & Good \\
\hline 5 & $\begin{array}{l}\text { El Limón } \\
\text { stream }\end{array}$ & $\begin{array}{l}\text { 606437E, } \\
\text { 9571676S }\end{array}$ & $\checkmark$ & $\checkmark$ & $\checkmark$ & $\checkmark$ & $\begin{array}{l}\text { Below } \\
\text { average }\end{array}$ & Poor & $\begin{array}{c}\text { Below } \\
\text { average }\end{array}$ \\
\hline 6 & $\begin{array}{l}\text { El Guineo } \\
\text { stream }\end{array}$ & $\begin{array}{l}\text { 598773E, } \\
\text { 9567082S }\end{array}$ & $\checkmark$ & & $\checkmark$ & & $\begin{array}{c}\text { Below } \\
\text { average }\end{array}$ & Poor & $\begin{array}{l}\text { Below } \\
\text { average }\end{array}$ \\
\hline 7 & Gringo Beach & $\begin{array}{l}\text { 600022E, } \\
9573244 \mathrm{~S}\end{array}$ & $\checkmark$ & & $\checkmark$ & $\checkmark$ & $\begin{array}{c}\text { Below } \\
\text { average }\end{array}$ & Poor & Good \\
\hline 8 & $\begin{array}{c}\text { Las } \\
\text { Concreciones } \\
\text { stream }\end{array}$ & $\begin{array}{l}\text { 602810E, } \\
9570930 \mathrm{~S}\end{array}$ & $\checkmark$ & $\checkmark$ & & & Poor & Poor & $\begin{array}{l}\text { Below } \\
\text { average }\end{array}$ \\
\hline
\end{tabular}


Table 5. Cont.

\begin{tabular}{|c|c|c|c|c|c|c|c|c|c|}
\hline \multirow{2}{*}{$\mathbf{N}^{\circ}$} & \multirow{2}{*}{ LIGs } & \multirow{2}{*}{$\begin{array}{c}\text { UTM } \\
\text { Coordinates }\end{array}$} & \multicolumn{4}{|c|}{ Type of Interest } & \multirow{2}{*}{ Accessibility } & \multirow{2}{*}{ Sensitivity } & \multirow{2}{*}{$\begin{array}{c}\text { Conservation } \\
\text { Status }\end{array}$} \\
\hline & & & Si & Di & Ti & $\mathbf{P i}$ & & & \\
\hline 9 & $\begin{array}{l}\text { Las Palmas } \\
\text { stream }\end{array}$ & $\begin{array}{l}\text { 600442E, } \\
9571602 \mathrm{~S}\end{array}$ & $\checkmark$ & & $\checkmark$ & $\checkmark$ & $\begin{array}{c}\text { Below } \\
\text { average }\end{array}$ & Poor & Good \\
\hline 10 & $\begin{array}{l}\text { Quemazón } \\
\text { stream }\end{array}$ & $\begin{array}{l}\text { 603298E, } \\
9570534 S\end{array}$ & & & $\checkmark$ & & Good & Poor & $\begin{array}{c}\text { Below } \\
\text { average }\end{array}$ \\
\hline 11 & Tunima stream & $\begin{array}{l}612035 \mathrm{E}, \\
9570322 \mathrm{~S}\end{array}$ & & & $\checkmark$ & & $\begin{array}{c}\text { Below } \\
\text { average }\end{array}$ & Poor & Good \\
\hline 12 & $\begin{array}{l}\text { Puyango River } \\
\text { course }\end{array}$ & $\begin{array}{l}\text { 601926E, } \\
9570859 \mathrm{~S}\end{array}$ & & $\checkmark$ & $\checkmark$ & & Regular & Poor & $\begin{array}{c}\text { Below } \\
\text { average }\end{array}$ \\
\hline 13 & $\begin{array}{l}\text { Puyango-Alamor } \\
\text { trail }\end{array}$ & $\begin{array}{l}\text { 602305E, } \\
9567823 \mathrm{~S}\end{array}$ & & $\checkmark$ & $\checkmark$ & & Good & Poor & $\begin{array}{c}\text { Below } \\
\text { average }\end{array}$ \\
\hline 14 & El Tigre stream & $\begin{array}{l}\text { 605566E, } \\
9571653 \mathrm{~S}\end{array}$ & $\checkmark$ & $\checkmark$ & & & Good & $\begin{array}{c}\text { Below } \\
\text { average }\end{array}$ & Average \\
\hline 15 & $\begin{array}{l}\text { La Libertad } \\
\text { fold }\end{array}$ & $\begin{array}{l}\text { 600021E, } \\
9573243 S\end{array}$ & $\checkmark$ & $\checkmark$ & & & $\begin{array}{c}\text { Below } \\
\text { average }\end{array}$ & $\begin{array}{c}\text { Below } \\
\text { average }\end{array}$ & $\begin{array}{c}\text { Below } \\
\text { average }\end{array}$ \\
\hline 16 & $\begin{array}{c}\text { Playón Las } \\
\text { Pailas }\end{array}$ & $\begin{array}{l}\text { 606828E, } \\
9571865 S\end{array}$ & & & $\checkmark$ & $\checkmark$ & Good & $\begin{array}{c}\text { Below } \\
\text { average }\end{array}$ & Average \\
\hline 17 & $\begin{array}{c}\text { PPF } \\
\text { Interpretation } \\
\text { Center }\end{array}$ & $\begin{array}{c}601354 \mathrm{E} \\
9568864 \mathrm{~S}\end{array}$ & & $\checkmark$ & $\checkmark$ & $\checkmark$ & Good & $\begin{array}{c}\text { Below } \\
\text { average }\end{array}$ & $\begin{array}{c}\text { Below } \\
\text { average }\end{array}$ \\
\hline
\end{tabular}

\subsection{Strategies}

The results obtained through a SWOT analysis, which required extensive geological-paleontological fieldwork with experts and people from the community, are presented in Table 6. The authors took the Sustainable Development Goals (SDGs) into account to obtain strategies in terms of sustainable geotourism.

Table 6. Matrix of Strengths, Weaknesses, Opportunities, and Threats (SWOT) of the Puyango Petrified Forest.

\begin{tabular}{|c|c|c|}
\hline & Strengths & Weaknesses \\
\hline External environment & $\begin{array}{l}\mathrm{S}_{1} \text {. Puyango is the unique } \\
\text { petrified forest of } \\
\text { Cretaceous-Aptian age in the } \\
\text { country and it has international } \\
\text { relevance. } \\
\mathrm{S}_{2} \text {. It has an outstanding scientific } \\
\text { interest due to the exceptional } \\
\text { type of fossilization of the } \\
\text { petrified trunks. } \\
\mathrm{S}_{3} \text {. It was declared the Ecuadorian } \\
\text { a Cultural Heritage Treasure. } \\
\mathrm{S}_{4} \text {. The unique forest that } \\
\text { combines petrified and natural } \\
\text { trees. It is the habitat of } 65 \text { species } \\
\text { of birds and other animals. }\end{array}$ & $\begin{array}{l}\mathrm{W}_{1 .} \text { Lack of "social awareness" } \\
\text { necessary in a } \\
\text { geological-paleontological and } \\
\text { cultural heritage. } \\
\mathrm{W}_{2} \text {. Lack of infrastructure and } \\
\text { tourist care services (emergency } \\
\text { ward, restaurants, and lodgings). } \\
\mathrm{W}_{3} \text {. Lack of a bilingual tourist } \\
\text { information center that provides } \\
\text { scientific and relevant information } \\
\mathrm{W}_{4} \text {. Lack of internet access and } \\
\text { media communications. }\end{array}$ \\
\hline Opportunities & $\begin{array}{l}\text { Strategy: } \\
\text { Strengths + Opportunities }\end{array}$ & $\begin{array}{l}\text { Strategy: } \\
\text { Weaknesses + Opportunities }\end{array}$ \\
\hline
\end{tabular}


Table 6. Cont.

\begin{tabular}{|c|c|c|}
\hline $\begin{array}{l}\mathrm{O}_{1} \text {. Geopark Project proposal under development by } \\
\text { government entities and universities. } \\
\mathrm{O}_{2} \text {. Protection and restoration of LIGs through } \\
\text { various strategies with national and international } \\
\text { organizations. } \\
\mathrm{O}_{3} \text {. Geotourism development open to improvement. } \\
\mathrm{O}_{4} \text {. Declare PPF as a Biosphere Reserve (BR) in the } \\
\text { dry forest of southern Ecuador. It is a strategic } \\
\text { opportunity. }\end{array}$ & $\begin{array}{l}\mathrm{S}_{1} \mathrm{O}_{1} \text {. Complement studies to } \\
\text { generate a database of scientific } \\
\text { information on paleontological } \\
\text { resources. } \\
\mathrm{S}_{2} \mathrm{O}_{2} \text {. Develop strategies for the } \\
\text { sustainable management of } \\
\text { cultural and natural resources: } \\
\text { conservation, research, and } \\
\text { development for the proposal of } \\
\text { the Puyango Geopark project. } \\
\mathrm{S}_{3} \mathrm{O}_{3} \text {. Undertake conservation } \\
\text { and cleaning work on fossil } \\
\text { outcrops, protection of specimens } \\
\text { in situ, an adaptation of trails and } \\
\text { placement of information panels. }\end{array}$ & $\begin{array}{l}\mathrm{W}_{1} \mathrm{O}_{1} \text {. Participatory Geopark } \\
\text { proposal that integrates } \\
\text { geodiversity, biodiversity, territory } \\
\text { and people. } \\
\mathrm{W}_{2} \mathrm{O}_{2} \text {. Promote Social } \\
\text { Management programs (training } \\
\text { and awareness) that involve rural } \\
\text { families in the management of } \\
\text { resources. } \\
\mathrm{W}_{4} \mathrm{O}_{4} \text { Promote the management } \\
\text { of information, production and } \\
\text { popularization of knowledge and } \\
\text { tourism promotion at national and } \\
\text { international level, through ICTs. }\end{array}$ \\
\hline Threats & $\begin{array}{l}\text { Strategy: } \\
\text { Strength + Threats }\end{array}$ & $\begin{array}{l}\text { Strategy: } \\
\text { Weaknesses + Threats }\end{array}$ \\
\hline $\begin{array}{l}\mathrm{T}_{1} \text {. The burning of vegetation to obtain new land for } \\
\text { planting. } \\
\mathrm{T}_{2} \text {. Deforestation and overgrazing that degrades the } \\
\text { ecosystem. } \\
\mathrm{T}_{3} \text {. Collection of samples without approval from } \\
\text { Authorities. } \\
\mathrm{T}_{4} \text {. Demand from the neighboring country Peru for } \\
\text { the pollution of the Puyango River due to mining } \\
\text { effects outside the PPF [36]. } \\
\mathrm{T}_{5} \text {. Possible landslides, river floods and climatic } \\
\text { variations due to severe droughts. }\end{array}$ & $\begin{array}{l}\mathrm{S}_{2 .} \mathrm{T}_{4} \text {. Encourage the development } \\
\text { of good bilateral relations with the } \\
\text { neighboring country Peru. This } \\
\text { strategy stabilizes the intra-border } \\
\text { situation and encourages Peruvian } \\
\text { tourism to the PPF area. } \\
\mathrm{S}_{3 .} \mathrm{T}_{3} \mathrm{~T}_{4} \text {. Recovery of the } \\
\text { paleontological deposit of fossil } \\
\text { outcrops of trees and marine } \\
\text { invertebrates from the PPF and } \\
\text { nearby areas such as the Piedmont } \\
\text { of the Tumbesina eco-region } \\
\text { (Ecuador-Peru). } \\
\mathrm{S}_{4} \mathrm{~T}_{3} \text {. Legal regulations with } \\
\text { permanent control on all activities } \\
\text { within the forest, such as trail } \\
\text { management, conservation, staff } \\
\text { performance, tour operators, } \\
\text { transportation income, } \\
\text { agricultural production, etc. }\end{array}$ & $\begin{array}{l}\mathrm{W}_{1 .} \mathrm{T}_{1} \text {. Promote sustainable } \\
\text { tourism and mitigation of local } \\
\text { anthropogenic threats. } \\
\mathrm{W}_{2 .} \mathrm{T}_{2} \text {. To plan and promote the } \\
\text { reforestation in selected areas } \\
\text { through a pilot program, all } \\
\text { together with farm owners within } \\
\text { the forest has protected area to } \\
\text { establish a mining-environmental } \\
\text { order. } \\
\mathrm{W}_{3} \mathrm{~T}_{3} \text {. Find private investors for } \\
\text { the construction of a tourist } \\
\text { accommodation and recreation } \\
\text { center. } \\
\mathrm{W}_{4} \mathrm{~T}_{4} \text {. Build a permanent } \\
\text { Information Center and } \\
\text { administrative offices, according } \\
\text { to the regulations to certify the } \\
\text { area as an eco-touristic site. }\end{array}$ \\
\hline
\end{tabular}

\section{Discussion}

The results obtained based on the IELIG's methodology provided data for both a quantitative and qualitative analysis, where the experts in geological, paleontological and archaeological sciences highlighted the forest's value as a unique example of the Cretaceous Period at a national level, which requires the recovery and preservation of its importance of the PPF as an Ecuadorian unique example of the Cretaceous Period, which requires the recovery and conservation of its heritage for sustainable development [37]. Additionally, the analysis suggested that the geotourism alternative supports the "Puyango" Geopark project. Experts have considered a referential assessment from 17 LIGs taken in the forest which on average are described as "below average" accessibility, "poor" sensibility and a "below average" conservations state that supports the usage of strategies to enhance the development of this area destinated for the geotourism as a pedagogical tool; it also promotes the restitution and improvement of geological and paleontological informative panels. Thus, it is essential to incorporate a web page to strengthen and increase the influx of tourists in the area, where the site is scientific and cultural information is disseminated nationally and internationally and to keep a record of annual visits. 
The methodological study allows considering the PPF as a Geological Interest Place (LIG, acronym in Spanish) for the geological, paleontological, historical and cultural environment that surrounds it. The results evidenced to "Very high" geological interest in the LIGs "PPF Touristic trail", "Sábalos stream", "El Limón stream" and "PPF Interpretation Center"; "High" geological interest in "Cochurco stream", "Chirimoyo stream", "El Guineo stream", "Gringo Beach", "Las Concreciones stream", "Quemazón stream", “Tunima stream", “El Tigre stream" and "Playón Las Pailas" highlighting the paleontology of the place. The LIG Protection Priority (PP) scores classified as "Medium-low" in most LIGs; this is because the Puyango Petrified Forest (PPF) is a protected natural reserve of public administration, which gives it the competence and authority to management and protection policies. The LIGs to "PPF Touristic trail" and "PPF Interpretation Center" have a "High" rating of Protection Priority since they have a high influx of national and international visitors [17]. In the assessment, vulnerability to plunder also responded to the anthropic threat caused directly by collectors as the paleontological appeal is an intrinsic characteristic of the geosite. Therefore, knowing its PP fosters the adoption of measures for the conservation of the LIG [38,39].

Despite having high values in the geological-paleontological interest, it is necessary to monitor PPF, implement the proposed strategies and analyze its tourist development since it has 13,000 visitors per year, $70 \%$ are domestic tourists and 30\% foreign [40]. Furthermore, the present study identifies shortcomings in terms of the infrastructure, as the place demands services for tourists such as accommodation, restaurants, a health care center and internet access and media communication. Nevertheless, PPF, with just 2659 hectares, has great potential compared to other forests with a large concentration of petrified wood such as the Jaramillo Petrified Forest National Park in Santa Cruz-Argentina of the Middle-Upper Jurassic Period [41]. The latter has 15,000 hectares and an average of 4800 tourists a year. Another case is the Petrified Forest National Park in Arizona, United States, of the Triassic Period, that includes more than 20,000 ha and around 5800 visitors per year [42,43].

Therefore, the results obtained in this study were satisfactory and provided necessary information to evaluate possible threats that affect the forest and its heritage in a natural environment and to boost the execution and implementation of scientific and territorial ordering in projects according to the population's capacity and the reality of the site [44,45].

\section{Conclusions}

The assessment of the methodology of the Spanish Inventory of Places of Geological Interest (IELIG, acronym in Spanish) carried out on seventeen different stations in the Puyango Petrified Forest, proved that it is a Place of Geological Interest (LIG, acronym in Spanish). Thus, PPF is in the categories of Very high and High interest in the scientific, tourist and educational sectors, for its great potential and geological relevance to promote geotouristic development.

The geodiversity of the forest is the main strength of the area, since it is considered a geological-paleontological heritage site, for purposes of touristic interpretation. PPF is one of the few sites in the world where you can analyze the paleontological aspects of the prehistoric flora and relate it to the current plant landscape. These characteristics make PPF an icon of geotourism in the sector. Hence, the proposed methodology SDTPI-ASC assessed the 17 LIGs in a preliminary stage and gave PPF a great value as a place of geological-paleontological heritage. Moreover, this analysis is a significant contribution to academia and its application facilitates the recognition of LIGs. Thus, the geopark project generates an alternative for the scientific, cultural and economic development of the population through a territorial order that addresses the 2030 Agenda and contains 17 Sustainable Development Goals (SDGs).

The importance of anthropogenic threats (deforestation, overgrazing, sample collection, burning of vegetation for new land and planting) and natural threats (landslides, river floods, severe droughts) faced by the geosites urge the protection and conservation of the LIGs. Therefore, strategies will substantially improve environmental, geological and paleontological conservation, as well as community participation and dissemination in the short and long term. 
Finally, the development of bilateral relations with the neighboring country Peru will stabilize the intra-border situation and encourage Peruvian tourism to the PPF area. In addition, it will promote relations with international organizations interested in supporting the proposal for the sustainable conservation and resource management of the Puyango geopark project.

Supplementary Materials: The following are available online at http://www.mdpi.com/2071-1050/12/16/6579/s1, in the book "PUYANGO: ENTRE PASADO Y PRESENTE" ("PUYANGO: BETWEEN PAST AND PRESENT") of the Valuation Study of the Petrified Forest of Puyango, Loja Province, Ecuador. First edition, Guayaquil-Ecuador, 2004, ISBN: 9978-310-07 [26], Figure S1: Macrofossils, Figure S2: Macrofossils, Figure S3: Microfossils, Figure S4: Microfossils.

Author Contributions: Conceptualization, P.C.-M., F.M.-C. and N.J.-O.; methodology, F.M.-C., G.H.-N., N.J.-O. and P.C.-M.; software, G.H.-N.; validation, P.C.-M., N.J.-O. and F.M.-C.; formal analysis, F.M.-C., G.H.-N., N.J.-O. and P.C.-M.; investigation, N.J.-O., F.M.-C. and G.H.-N.; resources, F.M.-C., G.H.-N., N.J.-O. and P.C.-M.; data curation, N.J.-O., G.H.-N. and F.M.-C.; writing-original draft preparation, N.J.-O. and G.H.-N.; writing-review and editing, P.C.-M., F.M.-C., N.J.-O. and G.H.-N.; visualization, F.M.-C., G.H.-N., N.J.-O. and P.C.-M.; supervision, F.M.-C. and N.J.-O.; project administration, N.J.-O and F.M.-C.; funding acquisition, N.J.-O. All authors have read and agreed to the published version of the manuscript.

Funding: This work was supported by ESPOL Research projects: “Estudio de Valoración y Diagnóstico de Paleontología, Botánica, Arqueología y Etnografía en Puyango, Celica y Paltas, Provincia de Loja" (Study of assessment and diagnosis of paleontology, botany, archaeology and ethnography in Puyango, Celica and Paltas, Loja province), "Propuesta de Geoparque Ruta del Oro y su incidencia en el desarrollo territorial" ("Ruta del Oro" Geopark proposal and its impact on territorial development) under grant nos CIPAT-02-2018 and "Registro del Patrimonio Geológico y Minero y su incidencia en la defensa y preservación de la geodiversidad en Ecuador" (Registry of Geological and Mining Heritage and its impact on the defense and preservation of geodiversity in Ecuador) under grant nos CIPAT-01-2018.

Acknowledgments: The authors wish to acknowledge Ivan Romero and Josue Briones for their support and recommendations in the preparation of this research.

Conflicts of Interest: The authors declare no conflict of interest.

\section{References}

1. Štrba, L.; Kolackovská, J.; Kudelas, D.; Kršák, B.; Sidor, C. Geoheritage and geotourism contribution to tourism development in protected areas of Slovakia-theoretical considerations. Sustainability 2020, 12, 2979. [CrossRef]

2. Williams, M.A.; McHenry, M.T.; Boothroyd, A. Geoconservation and Geotourism: Challenges and Unifying Themes. Geoheritage 2020, 12,1-14. [CrossRef]

3. Lopes, R.F.; Candeiro, C.R.A.; de Valais, S. Geoconservation of the paleontological heritage of the geosite of dinosaur footprints (sauropods) in the locality of São Domingos, municipality of Itaguatins, state of Tocantins, Brazil. Environ. Earth Sci. 2019, 78. [CrossRef]

4. Shekhar, S.; Kumar, P.; Chauhan, G.; Thakkar, M.G. Conservation and Sustainable Development of Geoheritage, Geopark, and Geotourism: A Case Study of Cenozoic Successions of Western Kutch, India. Geoheritage 2019, 11, 1475-1488. [CrossRef]

5. Ferreira, A.R.R.; Lobo, H.A.S.; de Jesus Perinotto, J.A. Inventory and Quantification of Geosites in the State Tourist Park of Alto Ribeira (PETAR, São Paulo State, Brazil). Geoheritage 2019, 11, 783-792. [CrossRef]

6. Dowling, R.K. Geotourism's Global Growth. Geoheritage 2011, 3, 1-13. [CrossRef]

7. Hurtado, H.; Dowling, R.; Sanders, D. An Exploratory Study to Develop a Geotourism Typology Model. Int. J. Tour. Res. 2006, 8. [CrossRef]

8. Newsome, D.; Dowling, R. Geoheritage and geotourism. In Geoheritage: Assessment, Protection, and Management. Elsevier. Inc. 2018, 17, 305-321. [CrossRef]

9. Dos Reis Polck, M.A.; de Medeiros, M.A.M.; deAraújo-Júnior, H.I. Geodiversity in Urban Cultural Spaces of Rio de Janeiro City: Revealing the Geoscientific Knowledge with Emphasis on the Fossil Content. Geoheritage 2020, 12. [CrossRef]

10. Tavares, G.N.D.; Boggiani, P.C.; de Moraes Leme, J.; Trindade, R.I. The Inventory of the Geological and Paleontological Sites in the Area of the Aspirant Geopark Bodoquena-Pantanal in Brazil. Geoheritage 2020, 12. [CrossRef] 
11. Morales, J.; Azanza, B.; Gómez, E. El Patrimonio Paleontológico Español. Coloq. de Paleontol. 1999, 50, 53-62. (In Spanish)

12. Gutiérrez, J. Determinación de la metodología límites aceptables de cambio como estrategia para el manejo del ecoturismo en el Bosque Petrificado Puyango. Third level. Bachelor's Thesis, Machala Technical University, Machala, Ecuador, October 2015. (In Spanish).

13. Meléndez, G. Definición y Valoración de la Geodiversidad, Análisis, Valoración y Protección Legal del Patrimonio Geológico y Paleontológico. Bachelor's Thesis, Zaragoza University, Bilbao, Spain, 13 May 2010.

14. Ordoñez, M.; Jiménez, N.; Suárez, J. Micropaleontología Ecuatoriana; Petroproducción, Guayaquil Geological Research Center, CIGG.: Guayaquil, Ecuador, 2006. (In Spanish)

15. Ministerio del Ambiente del Ecuador. 2007. Plan Estratégico del Sistema Nacional de Áreas Protegidas del Ecuador 2007-201 (SNAP-GEF). REGLA-ECOLEX. Quito. Available online: http://maetransparente. ambiente.gob.ec/documentacion/WebAPs/PLAN\%20ESTRATEGICO\%20DEL\%20SNAP.pdf (accessed on 14 December 2019).

16. Yaguachi, B. Identificación y dinamización del Corredor de Endemismo Tumbesino, sector Bosque Petrificado de Puyango. Bachelor's Thesis, Loja National University, Loja, Ecuador, 2012. (In Spanish).

17. Instituto Espacial Ecuatoriano (IEE) y MAGAP (SINAGAP). Generación de Geoinformación Para la Gestión del Territorio a Nivel Nacional; Technical Memory (Geomorphology): Puyango Canton, Ecuador, 2013. (In Spanish)

18. García, A.; Carcavilla, L. Documento Metodológico Para la Elaboración del Inventario Español de Lugares de Interés Geológico (IELIG); IGME Geological and Mining Heritage Research Area: Madrid, Spain, 2013. (In Spanish)

19. Aguirre, Z.; Lopez, G. Conservations status of the dry forests of the province of Loja, Ecuador. Arnaldoa 2017, 24, 207-228. [CrossRef]

20. Carrión, P.; Herrera, G.; Briones, J.; Caldevilla, P. Geotourism and Development Base on Geological and Mining Site Utilization, Zaruma-Portovelo, Ecuador. Geosciences 2018, 6, 205. [CrossRef]

21. Jaramillo, J.; García, T.; Bolaños, M. Bosque Petrificado de Puyango y sus Alrededores: Inventario de Lugares de Interés Geológico; GEO Latitud, Publisher: Quito, Ecuador, 2017; Volume 1. (In Spanish)

22. Gobierno Autónomo Descentralizado Municipal de Puyango. Plan de Desarrollo y Ordenamiento Territorial. 2014-2019. Available online: https://www.puyango.gov.ec. (accessed on 16 December 2019).

23. Conservación de la Diversidad Biológica en Los Bosques Tropicales Bajo Régimen de Ordenación; UICN: Gland, Suiza y Cambridge, Reino Unido, 1992-1995; Volume Xii, p. 272. ISBN 2-8317-0251-8.

24. Jiménez, H. Valoración de los servicios ecosistémicos de recreación y belleza escénica del Bosque Petrificado Puyango, 2015. Bachelor's Thesis, Loja Private Technical University, Loja, Ecuador, 2017. (In Spanish).

25. Pũ̃o, N. Environmental Management of the Puyango-Tumbes River Basin in Ecuador and Perú. Securing Water and Wastewater Systems: Global Experiences; Springer International Publishing: Cham, Switzerland, 2014; Volume 8, pp. 161-187. [CrossRef]

26. Xomchuck, I.; Jimenez, N.; Valverde, F. PUYANGO: Entre pasado y presente. Estudio de Valoración del Bosque Petrificado de Puyango, Provincia de Loja, Ecuador, 1st ed.; ESPOL: Guayaquil, Ecuador, 2004; pp. 9-60. (In Spanish)

27. Martz, J.W.; Parker, W.G. Revised lithostratigraphy of the Sonsela Member (Chinle Formation, Upper Triassic) in the southern part of Petrified Forest National Park, Arizona. PLoS ONE 2010, 5, e09329. [CrossRef] [PubMed]

28. National Secretary of Planning and Development and National Information System, Information for planning and territorial planning, National Geographic Atlas. 2013. Available online: http://sni.gob.ec/atlas-geograficonacional-2013. (accessed on 19 January 2020).

29. Jiménez, N.; Ordóñez, M.; Suárez, J.; Tigreros, J. Estudio de Valoración y Diagnóstico de Paleontología, Botánica, Arqueología y Etnografía en los Cantones de Puyango, Celica y Paltas de la Provincia de Loja, 2001-2002, Paleontología y Micropaleontología del Bosque Petrificado de Puyango Provincia de Loja; Proyecto de Loja, Vol. 1; CEAA-ESPOL: Guayaquil, Ecuador, 2004. (In Spanish)

30. Xomchuk, I.; Ramos, G.; Avilés, G. Estudio de Valoración y Diagnóstico de Paleontología, Botánica, Arqueología y Etnografía en los Cantones de Puyango, Celica y Paltas de la Provincia de Loja, 2001-2002, Valoración Socio-Etnográfica de los Cantones Puyango, Celica y Paltas; Proyecto de Loja, Vol. 2; CEAA-ESPOL: Guayaquil, Ecuador, 2004. (In Spanish)

31. Zhunaula, V. Análisis de los Factores Potenciales que inciden en el hurto del patrimonio cultural en el Bosque Petrificado Puyango. Bachelor's Thesis, Machala Technical University, Machala, Ecuador, 2016. (In Spanish). 
32. Cartuche, D.V.; Armijos, L.A.; Romero, C.S.; Ocampo, C.H. Evaluación del desarrollo turístico en el Bosque Petrificado de Puyango (BPP), sur de Ecuador. Rev. Espac. 2019, 40, 23.

33. Calva-Nagua, D.X. El desafío de las Fuentes arqueológicas para la educación ecuatoriana. Maestros y Sociedad 2018, 15, 393-408. (In Spanish)

34. Carrión-Mero, P.; Loor-Oporto, O.; Andrade-Ríos, H.; Herrera-Franco, G.; Morante-Carballo, F.; Jaya-Montalvo, M.; Aguilar-Aguilar, M.; Torres-Peña, K.; Berrezueta, E. Quantitative and Qualitative Assessment of the "El Sexmo" Tourist Gold Mine (Zaruma, Ecuador) as A Geosite and Mining Site. Resources 2020, 9, 28. [CrossRef]

35. García, J.; Falaschi, P.; Zamuner, A. Fungal-arthropod-plant interactions from the Jurassic petrified forest Monumento Natural Bosques Petrificados, Patagonia, Argentina. Palaeogeogr. Palaeoclimatol. Palaeoecol. 2012, 329-330, 37-46. [CrossRef]

36. Woodcock, D.; Meyer, H.; Dunbar, N.; Mclntosh, W. Geologic and taphonomic context of El Bosque Petrificado Piedra Chamana (Cajamarca, Peru). Geol. Soc. Am. Bull. 2009, 121, 1172. [CrossRef]

37. Tarras-Wahlberg, N.H.; Flachier, A.; Lane, S.N.; Sangfors, O. Environmental impacts and metal exposure of aquatic ecosystems in rivers contaminated by small scale gold mining: The Puyango River basin, souther Ecuador. Sci. Total Environ. 2001, 278, 239-261. [CrossRef]

38. Salazar, S. Propuesta de un Plan de comunicación para promocionar, localmente, al bosque petrificado Puyango, ubicado en las provincias ecuatorianas de El Oro y Loja, como una novedosa alternativa turística. Bachelor's Thesis, Las Americas University, Quito, Ecuador, 2010. (In Spanish).

39. Carcavilla. Geodiversidad y Patrimonio Geológico. Instituto Geológico y Minero de España; Edición Parques Nacionales: Madrid, Spanish, 2014; p. 21, NIPO: 474-11-012-3. (In Spanish)

40. Gómez, J.; Magnin, L. Cartography of Geomorphological Units of the Bosques Petrificados de Jaramillo National Park (Santa Cruz Argentina) for its Geo-Archaeological Implementation. Inst. De Geogr. Unam 2019, 98. [CrossRef]

41. Baranyi, V.; Reichgelt, T.; Olsen, P.E.; Parker, W.G.; Kurschner, W.M. Norian vegetation history and related environmental changes: New data from the Chinle Formation, Petrified Forest National Park (Arizona, SW USA). Bolletin Geol. Soc. Am. 2018, 130, 775-795. [CrossRef]

42. Núñez, P.; Vejsbjerg, L. El Turismo, entre la actividad económica y el derecho social en El Parque Nacional Nahuel Huapi, Argentina, 1934-1955. Estud. Y Perspect. En. Tur. 2010, 19, 930-945. (In Spanish)

43. Aragón, S.; Woodcock, D. Plant Community Structure and Conservation of a Northern Peru Sclerophullous Forest. Biotropica 2010, 42, 262. [CrossRef]

44. Herrera-Franco, G.; Carrión-Mero, P.; Alvarado, N.; Morante-Carballo, F.; Maldonado, A.; Caldevilla, P.; Briones-Bitar, J.; Berrezueta, E. Geosites and Georesources to Foster Geotourism in Communities: Case Study of the Santa Elena Peninsula Geopark Project in Ecuador. Sustainability 2020, 12, 4484. [CrossRef]

45. Štrba, L'; Kršák, B.; Sidor, C. Some Comments to Geosite Assessment, Visitors, and Geotourism Sustainability. Sustainability 2018, 10, 2589. [CrossRef]

(C) 2020 by the authors. Licensee MDPI, Basel, Switzerland. This article is an open access article distributed under the terms and conditions of the Creative Commons Attribution (CC BY) license (http://creativecommons.org/licenses/by/4.0/). 